NBER WORKING PAPER SERIES

\title{
CROSS-COUNTRY CAUSES AND CONSEQUENCES OF THE CRISIS:
} AN UPDATE

\author{
Andrew K. Rose \\ Mark M. Spiegel \\ Working Paper 16243 \\ http://www.nber.org/papers/w16243
NATIONAL BUREAU OF ECONOMIC RESEARCH
1050 Massachusetts Avenue
Cambridge, MA 02138
July 2010

Rose thanks the Bank of Englamd FRBSF, INSEAD and the MAS for hospitality during the course of this research. For comments, we thank: Tobias Adrian, Mick Devereux, Marcel Fratzscher, Domenico Giannone, Sebnem Kalemli-Ozcan, Robert Kollman, Tommaso Monacelli, Romain Ranciere, and Martin Uribe. We also thank Gian Maria Milesi-Ferretti and Stijn Claessens and their co-authors for access to data sets. The views expressed below do not represent those of the Federal Reserve Bank of San Francisco, the Board of Governors of the Federal Reserve System, or the National Bureau of Economic Research. A current version of this paper, key output, and the main STATA data set used in the paper are available at http://faculty.haas.berkeley.edu/arose.

NBER working papers are circulated for discussion and comment purposes. They have not been peerreviewed or been subject to the review by the NBER Board of Directors that accompanies official NBER publications.

(C) 2010 by Andrew K. Rose and Mark M. Spiegel. All rights reserved. Short sections of text, not to exceed two paragraphs, may be quoted without explicit permission provided that full credit, including (C) notice, is given to the source. 
Cross-Country Causes and Consequences of the Crisis: An Update

Andrew K. Rose and Mark M. Spiegel

NBER Working Paper No. 16243

July 2010

JEL No. E65,F30

\begin{abstract}
$\underline{\text { ABSTRACT }}$
We update Rose and Spiegel (2009a, b) and search for simple quantitative models of macroeconomic and financial indicators of the "Great Recession" of 2008-09. We use a cross-country approach and examine a number of potential causes that have been found to be successful indicators of crisis intensity by other scholars. We check a number of different indicators of crisis intensity, and a variety of different country samples. While countries with higher income seemed to suffer worse crises, we find few clear reliable indicators in the pre-crisis data of the incidence of the Great Recession. Countries with current account surpluses seemed better insulated from slowdowns.
\end{abstract}

\author{
Andrew K. Rose \\ Haas School of Business Administration \\ University of California, Berkeley \\ Berkeley, CA 94720-1900 \\ and NBER \\ arose@haas.berkeley.edu \\ Mark M. Spiegel \\ Federal Reserve Bank of San Francisco \\ 101 Market Street \\ San Francisco, CA 94105 \\ mark.spiegel@sf.frb.org
}


Introduction

In the Spring of 2009, we collected a cross-country data set that we used for a number of purposes in Rose and Spiegel (2010a, b, hereafter "RS"). We were primarily interested in seeing which of the many possible causes of the "Great Recession" of 2008-09 could be linked empirically to the actual crisis. A large number of causes had been suggested as potential fundamental reasons for the global crisis which broke out in 2008. Our approach was purely cross-sectional; any plausible theory of the crisis should at least be able to explain its incidence across countries (we think of understanding the timing of the crisis as a substantially more difficult exercise). We considered the cross-country exercise to be intrinsically interesting, since there was no consensus at the time on the cause(s) for the crisis. Our reasoning was that if, for example, excessive house-price appreciation was "the fundamental" cause of the crisis (feel free to substitute financial leverage, credit growth, current account imbalance, or whatever), it should explain the incidence and severity of the crisis in a number of different countries, not just one. Determining the fundamental causes of the crisis would also be valuable in building a quantitative "early warning system" (EWS) of the sort that the G-20 had advocated. In the large, our analysis failed; we were essentially unable to find an empirical model of the crisis that could link any plausible set of potential causes of the crisis to its manifestations. We found that richer countries had systematically worse experiences, as did countries which experienced a sharper rise in the stock market in the years before the crisis. There was also some weak evidence that countries with closer trade linkages to the United States experienced less severe crises.

In this short paper, we update our analysis and check to see if our conclusions our robust to the arrival of more recent information. We use two types of new information: updated data and, more importantly, the emerging literature of relevance.

\section{$\underline{\text { The Data Set }}$}


The analysis we report below is conducted on the same broad cross-section of countries as RS. In particular, we examine all countries/territories with real GDP per capita of at least $\$ 10,000$ in 2003 , as well as those with real GDP per capita of at least $\$ 4,000$ and a population of at least one million. Our sample of countries is tabulated in Appendix Table A1. ${ }^{1}$

We begin by re-estimating the key results of our original work with updated data.

\section{Updating the MIMIC Model}

In RS we used a non-structural MIMIC (Multiple Indicator Multiple Cause) model of the crisis. This model uses different manifestations of the severity of the crisis across countries, each of which is viewed as an imperfect proxy for crisis intensity. Real GDP growth in 2008 was an obvious indicator of the crisis, and we used the forecasts (technically, backcasts) for 2008 real GDP growth that were available in early March 2009 from the Economist Intelligence Unit. Since financial variables are intrinsically forward-looking and the crisis was financial in nature, we also used three different manifestations from different financial markets. In particular, we used 2008 changes in: a) the national stock market (from national sources), and b) the multilateral (SDR) exchange rate (from the IMF's International Financial Statistics), as well as c) the difference in country credit ratings between March 2008 and March 2009 as measured by Institutional Investor. The latter are ratings created by Institutional Investor that rank over 170 countries on a scale between 0 and 100 where 100 represents the least likelihood of default (in March 2010, Norway, Luxembourg and Switzerland had scores over 90, while Haiti scored less than 20). ${ }^{2}$ These four variables collectively seem to deliver a reasonable view of the countries most affected by the 2008 crisis. For instance, Iceland always appears as the country most dramatically affected by the crisis, along with countries like Ukraine, Estonia, Latvia, Ireland and the UK.

In RS, we also considered a host of potential causes of the crisis, all dated 2006 and earlier. Our reasoning was that this would be a data frequency of interest to policy-makers, since higher-frequency 
early warning systems may not provide enough time for policy to respond appropriately. Using 2006 data to measure potential causes also allows one to escape much of the endogeneity bias that might result from using later data, since policy authorities responded forcefully to the crisis. In RS, we considered both national causes of the crisis and a larger number of international linkages between countries and the countries that could plausibly be considered as the epi-centers of the crisis. For example, in trying to determine why Iceland experienced a 90\% drop in both its stock market and exchange rate in 2008 (as well as a substantial drop in its country credit rating and a domestic recession), we considered both national features of Iceland's economy (e.g., its credit/GDP rating) and international linkages between Iceland and say the United States, a plausible epi-center of the crisis (e.g., the share of 2006 Icelandic external assets held in America and the share of Icelandic exports going to the US). However we found only two reasonably robust positive results. We found that richer countries experienced more dramatic crises, as did countries with a larger run-up in the stock market (measured relative to output) before the crisis. We also found weaker evidence that countries with closer trade linkages to the United States also experienced somewhat milder crises. In the analysis that follows, we consider all three of these potential causes of the crisis.

We have since updated our 2008 stock market and exchange rate observations in a straightforward way, from national sources and IFS respectively. Since 2010 country credit ratings have not yet been released (as of late May 2010) for Institutional Investor, we instead use comparable country risk ratings from Euromoney, a comparable trade magazine. ${ }^{3}$ For real GDP growth, we use the estimates for 2008 and 2009 growth taken from the most recent national "Country Reports" produced by the Economist Intelligence Unit as of April 29, 2010. We thus have both more data (since we have 2009 as well as 2008 growth rates) and better data (since the quality of the 2008 data has been improved by the hindsight another year affords). Of course these changes to the data set, however welcome, may not be that important. Our 2008-09 series are extremely highly correlated with our 2008 
series, as is shown in Figure 1. This contains four scatter-plots, one for each of the different consequences of the crisis (growth, as well as the changes in the stock market, exchange rate, and country bond rating). The correlations between the 2008 and 2008-09 series are all high, ranging from .69 (for stock market growth) to .82 (for GDP growth).

We link the manifestations of the Great Recession to causes using a Multiple Indicator Multiple Cause (MIMIC) model. The MIMIC model was introduced to econometrics by Goldberger (1972). The model consists of two sets of equations:

$$
\begin{aligned}
& \gamma_{i, j}=\beta_{j} \zeta_{i}+v_{i} \\
& \zeta_{i}=\gamma_{k} x_{i, k}+\zeta_{i}
\end{aligned}
$$

where: $y_{i, j}$ is an observation on crisis indicator $j$ for country $i, x_{i, k}$ is an observation for potential crisis cause $k$ for country $i ; \xi_{i}$ is a latent variable representing the severity of the crisis for country $i ; \beta$ and $\gamma$ are vectors of coefficients, and $v$ and $\zeta$ are mutually uncorrelated well-behaved disturbances with zero means and constant variances. ${ }^{4}$ Equation (1) links J consequences and manifestations of the crisis (denoted by y) to the unobservable measure of crisis severity. In practice, we model this measurement equation using our ( $J=4$ ) indications of the crisis (the 2008-09 national changes in: a) real GDP, b) the stock market, c) country risk, and d) the exchange rate). The second equation models the determination of the crisis as a function of $K$ causes (x's, dated 2006 or earlier).

By substituting (2) into (1), one derives a model which is no longer a function of the latent variable $\xi$. This MIMIC model is a system of J equations with right-hand-sides restricted to be proportional to each another. These proportionality restrictions constrain the structure to be a "onefactor" model of the latent variable; with the addition of normalization, they achieve identification of the parameters in (1) and (2). One of the features of the MIMIC model is that it explicitly incorporates 
measurement error about a key variable - the incidence and severity of the crisis - in a non-trivial and plausible way. We estimate our MIMIC models in STATA with GLLAMM; Rabe-Hesketh et al (2004) provide further details. The iterative estimation technique begins with adaptive quadrature which is followed by Newton-Raphson. We normalize and achieve identification by imposing a factor loading of unity on the stock market change.

In RS, we examined more than one hundred possible national determinants of the crisis ( $x^{\prime} \mathrm{s}$ ) suggested by the literature. We found that only two variables worked consistently well; the natural logarithm of 2006 real GDP per capita, and the percentage change in the stock market between 2003 and 2006. We also found weaker evidence that 2006 bilateral trade between a country and the United States (the likely epi-center of the 2008 crisis), measured as a proportion of the country's total 2006 trade, can be linked to crisis intensity. In particular, richer countries and countries which had experienced a larger stock market run-up seemed to suffer more serious crises. The same is true of countries less dependent on trade with the United States, though the evidence is weaker for the last finding. We use these three variables as our default "causes" of the 2008-09 crisis.

In the column at the extreme left of Table 1, we estimate our MIMIC model again, but now using 2008-09 data on crisis manifestations and our three causes. Our updated results are quite similar to those of RS in both economic and statistical terms. The effects of both real GDP per capita and the stock market run-up are negative and statistically significant; more of either is associated with a worse crisis. More American trade seemed to reduce crisis intensity, though the effect is only significantly different from zero at (a whisker) greater than the .1 level.

\section{New Results from the Literature}

While our original results seem to stand up to the scrutiny provided by extra data, we do not pursue them further here. A literature has since sprung up which diverges from our methodology in 
four respects: a) the measure of crisis intensity (the dependent variable); b) the potential causes of the crisis (the covariates); c) the estimation procedure used to link potential causes and consequences of the crisis; and d) the sample of countries under consideration. In order to see whether our results are incompatible with those of others, we now follow more closely in the steps of the literature.

\section{Measures of Crisis Intensity}

One of the attractions of the MIMIC model to us is the fact that it models the crisis as being imperfectly reflected through a number of measures. However, the norm in the subsequent literature has been to model the crisis using a single measure, typically some function of GDP growth. For instance, Lane and Milesi-Ferretti (2010) model real GDP growth over 2008-09; Blanchard et al (2010) use growth between 2008Q4 and 2009Q1 from which they subtract average growth over 1995-2007; and Berkmen et al (2009) use the revision to the forecast of 2009 growth made between the Springs of 2008 and 2009 (Giannone et al (2010) and Claessens et al (2010) use other functions of GDP). It should be noted that such measures of crisis intensity are almost always real; modeling measures of financial distress is rare (though see Claessens et al, 2010).

Rather than restrict ourselves to a single cross-country measure of the crisis, we cast our net widely, and examine seven measures, all of which are continuous. ${ }^{5}$ Our default measure of crisis intensity is real GDP growth for 2008-09, taken from the EIU Country Reports. RS were criticized for not taking account of underlying growth trends, so we also consider both: a) the change in growth between 2005-07 and 2008-09; and b) the change in growth between 1990-07 and 2008-09, following the logic of e.g., Blanchard et al (2010) and Lane and Milesi-Ferretti (2010). We also follow Berkmen et al (2010) in considering growth revisions; we consider the difference between the April 2008 World Economic Outlook forecast for 2009 real GDP growth and the forecast for 2009 real GDP growth made in the April 2009 WEO. A fifth measure of the extent of the crisis is the 2009 output gap as estimated in the 
November 2009 OECD Economic Outlook, though this measure is only available for OECD members. Next we consider consumption growth for 2008-09 following Lane and Milesi-Ferretti (2010); consumption is more directly relevant for welfare than output growth. Our last measure of crosscountry crisis intensity is a combination of the four variables we used in RS. In particular, we examine the first principal factor extracted from 2008-09 changes in the SDR exchange rate, the national stock market, real GDP, and Euromoney country risk ratings. ${ }^{6}$

All seven crisis measures that we consider are positively correlated with each other, but the measures are by no means identical. Figure 2 provides a comprehensive set of scatter-plots of each of our seven cross-country measures of crisis intensity graphed against the others; the bivariate correlation coefficients are recorded in Table $2 .^{7}$

\section{Causes of the Crisis}

After choosing a measure of crisis intensity (e.g., 2008-09 GDP growth), researchers have attempted to link their chosen dependent variable to potential causes of the crisis. These crisis determinants are often measured using data that precedes the crisis, as would be required in a functional EWS. For instance, in RS, we attempted to link over 100 potential crisis causes dated 2006 and earlier to crisis manifestations from 2008. A large number of different causes have been investigated, usually with limited success. A consensus seems to be developing that it is extremely difficult to understand the intensity of the crisis across countries using simple quantitative models. However, there are some successes.

Claessens et al (2010) find that only a few conditions preceded the crisis can be linked to the measures of performance during the crisis. In particular, they find that only house-price appreciation, bank credit growth, and the size of the current account can be sensibly and robustly linked to crisis incidence. Lane and Milesi-Ferretti (2010) and Berkmen et al (2009) also consider a large number of 
crisis causes and effects; both corroborate the finding that cumulative credit growth and fixed exchange rates affect crisis severity. Adrian and Shin (2008) provide a relevant discussion of credit growth. Berkmen et al (2009) also find that countries with greater financial leverage experienced worse crises, while Lane and Milesi-Ferretti (2010) find the current account is relevant for understanding crisis intensity; we had some success with both variables in RS. Giannone et al (2010) provide robust evidence that countries with more liberal credit market regulations suffered more serious crises. Both Blanchard et al (2010) and Lane and Milesi-Ferretti (2010) find that countries whose trading partners declined further during the crisis fared worse themselves. Blanchard et al (2010) demonstrate that the fraction of GDP held in short-term external debt is closely negatively linked to growth for developing countries. Frankel and Saravelos (2010) have some success with various measures of international reserves; Obstfeld et al (2009) find that reserves are of help in understanding depreciation during the period. A large number of other potential causes have been investigated but cannot be reliably linked to the crisis, including: the size of credit and debt in the economy; features of the domestic banking sector; fiscal policy; and foreign integration via both trade and capital flows. Many researchers (including Claessens et al (2010), Giannone et al (2010), Frankel and Saravelos (2010), and Lane and Milesi-Ferretti (2010)) corroborate RS in finding that countries with higher levels of real GDP per capita experienced more severe crises.

Investigating Potential Crisis Causes One by One

We now investigate the relevance of all the variables suggested by the literature as potential cross-country causes of the great recession. We begin by including them as covariates of crisis intensity, one by one (this should help alleviate multicollineaity problems). In RS we used a non-linear MIMIC procedure, but we follow the literature in using least squares since it prevailed as the estimation strategy of choice. Thus we use OLS to estimate equations of the form: 


$$
y_{i}=\phi x_{i}+\varepsilon_{i}
$$

where $\phi$ is a reduced-form coefficient linking a pre-crisis cause of the crisis $(x)$ to a crisis manifestatation (y) and $\varepsilon$ is a well-behaved disturbance.

We estimate our equations for a variety of different samples. We do this to check for sample sensitivity, to be able to compare our results easily with the literature, and to ensure that negative results do not stem from mixing together heterogeneous groups of countries. We examine six different samples of countries. Our full sample consists in up to 107 countries/territories that are either rich (real GDP per capita of at least $\$ 10,000$ in 2003) or reasonably well-off and large (real GDP per capita of at least $\$ 4,000$ and a population of at least one million). We also restrict this sample to consider five more narrow alternatives: a) 51 countries that the World Bank judges to be "high income"; b) 74 countries that are not considered by the IMF to be "advanced economies"; c) 89 countries that are not major oil exporters; d) 91 countries that are not small financial centers; and e) 51 countries that are either high or upper-middle income countries and are neither oil exporters nor small financial centers. The full sample of countries (along with relevant characteristics) is tabulated in Appendix Table A1. ${ }^{8}$

The nine panels of Table 3 each investigate one of the nine causes of the crisis that researchers have been able to link successfully to the intensity of the crisis. For instance, Table 3a examines whether countries with fixed exchange rate regimes seem to experience more intense crises. Successive panels of Table 3 report the effects of: the 2006 current account/GDP ratio; 2005-07 growth in trading partners; the 2006 degree of credit market regulation; the 2006 ratio of short-term external debt to GDP; the 2000-06 change in real housing prices; the 2000-06 growth in bank credit measured as a fraction of GDP; the 2006 level of bank credit, again measured as a fraction of GDP; and international reserves, also as a fraction of GDP. ${ }^{9}$ 
There are seven rows in each panel of Table 3, one for each of the seven different measures of crisis intensity (2008-09 real GDP growth, the 2009 output gap, etc.). There are also six different columns, one for each of the different sample of countries (all, high-income countries, etc.). Thus there are $(6 \times 7=) 42$ coefficient estimates tabulated, along with robust standard errors. Each of these coefficients is taken from a separate cross-country OLS regression; these regressions also included an unreported intercept and control for the natural logarithm of 2006 real GDP per capita. Coefficients that are significantly different from zero at the .05 (.01) significance level are marked with one (two) asterisk(s).

The results of Table 3 show that it is not trivial to link some plausible causes of the crisis to its intensity across countries, at least in a robust fashion. For instance, we have little success linking crises to fixed exchange rate regimes; the same is true of the effect of pre-crisis trading partner growth, and the ratio of credit to GDP. International reserves also do not seem to have consistent strong effects. ${ }^{10}$ But we do have some successes. Countries with pre-crisis current account surpluses seemed to weather the Great Recession better, as did countries which had experienced lower growth in bank credit beforehand. Like Giannone et al (2010), we find that countries with more liberal credit market regulation experienced significantly worse crises. ${ }^{11}$ The effects of the current account, credit growth, and credit market regulation are all somewhat sensitive to the exact country sample and measure of crisis intensity. Countries which have experienced more of a runup in the real housing price and those with more short-term external debt also seem to suffer worse crises, though the number of observations we have for both measures is limited (short-term external debt data is only available for 52 developing countries, and we use the 45 observations on real housing prices available from Claessens et al (2010)). ${ }^{12}$

To summarize, we find that some of the variables explored in the literature are correlated with crisis intensity across countries in our sample. The current account, credit market regulation, and credit 
growth are widely available variables which are associated with crisis in the Table 3 results; the fraction of GDP held in short-term external debt and the runup in real housing prices also seem to work, but are only available for a small number of countries. ${ }^{13}$

\section{Combining Potential Crisis Causes Together Simultaneously}

The results in Table 3 can be criticized, since they only control for the level of real GDP. Further, the potential causes are investigated one by one, not simultaneously. We now handle both those problems.

In Table 4, we include all of the potential causes of the crisis that we found to be successful in Table 3 and have large number of observations. In particular, we include simultaneously: a) the 2006 current account, expressed as a percentage of GDP; b) the 2006 credit market regulation, and c) bank credit growth between 2000 and 2006 (as a percentage of GDP). We also include as controls the three variables that we found to be successful in RS, namely: a) the log of 2006 real GDP per capita; b) the growth in a country's stock market/GDP ratio between 2003 and 2006; and c) the proportion of a country's trade going to the United States in 2006. Simple bivariate scatter-plots of growth against each of six regressors are provided in Figure 3. There are seven rows in Table 4, one for each of the seven different measures of crisis intensity (our dependent variable).

The results of Table 4 are sobering for those who believe in the viability of such cross-country early warning systems. None of the measures of crisis intensity is explained precisely; the equations do not fit the data well. The right-hand side variables have only been included after a fairly arduous process of winnowing, and yet a number seem to be insignificant when included simultaneously. For instance, neither the pre-crisis stock market run, nor trade linkages with the United States have significant effects on crisis intensity in any of the seven reported regressions. Other variables are almost as weak; the effect of bank credit growth is significant at the $5 \%$ level in one of the seven regressions, 
while the current account and income effects are different from zero at conventional levels in only two. The only variable that seems to have a robust effect is that of the degree of credit market regulation, which is significantly different from zero for six of the seven regressands. The crisis measure that can be most closely linked with the data is simple 2008-09 GDP growth; it is intuitively and strongly affected by three pre-crisis variables (2006 real per capita income, the current account and credit market regulations). Accordingly, we pursue this measure of crisis intensity in the analysis which follows. ${ }^{14}$

In Table 5a, we examine whether the links between 2008-09 growth and the six key regressors are robust to changes in the sample of countries. The default sample of all countries with available data is reported in the top row; this simply reproduces the top row of Table 4. The rows below present results for the five other samples of interest to us. Unfortunately even reasonable changes to the precise sample of countries have a large effect on the coefficient estimates. For instance, the significant effect of the current account vanishes almost entirely when the sample is changed, as is the effect of real income. Indeed, the only effect which is significantly different from zero in a majority of the samples is the negative effect of credit market regulation. Not all the news is negative; the goodness of fit varies little across samples, as do the signs (though not magnitudes) of most of the coefficients.

Table $5 b$ adds the two extra regressors of interest to the equation, using the full sample of available observations. Only the negative effect of short-term external debt survives, and its presence reduces the sample size considerably (since it is only available for developing countries), simultaneously knocking out the effects of the current account and real income.

The results in Table 6a show that even focusing the regressions more narrowly on these results still leaves an equation which is sensitive to the exact sample of countries. Only the external short-term debt ratio enters in a consistently robust fashion. On the other hand, weighting the regressions by a country's population has little effect, as shown in Table 6b. 
Is the absence of strong results the result of some non-linearity in the data which has not been modeled in our linear equations? While the graphical evidence in Figure 3 makes us skeptical about such a claim, we now pursue a semi-parametric approach to tease out any non-linearities of relevance.

We focus on the four regressors that seemed most highly correlated with (in Tables 5 and 6 ) and relevant for understanding real 2008-09 growth: the current account/GDP ratio, credit market regulations, log real GDP per capita, and short term external debt/GDP ratio, all measured in 2006 . We search for non-linearities variable by variable using a general non-parametric technique. However, we also take account of the potential linear effects of the (three) other key regressors. We follow a tedious but straightforward procedure. First, we choose a regressor of interest; say the current account/GDP ratio. Next, we account for the effects of the other regressors (credit market regulations, ...) by regressing 2008-09 growth on these other regressors, and retrieving the residual. Similarly, we regress the current account ratio on the other factors and take the residual. Finally, we regress the growth residual on the current account residual - both now purged of the effects of other regressors - using the non-parametric "locally weighted regression" technique which can capture arbitrary non-linearities. We plot fitted LWR relationships in Figure 4. There are four graphs, one for each key regressor. ${ }^{15}$ Unfortunately, no obvious threshold effects or useful non-linearities are apparent in Figure 4.

\section{Extending the Sample Period}

Suppose that one ignores the sensitivity of the results in Tables 4-6 and focuses only the positive results. The message one might be tempted to draw is that countries with current account surpluses, and more tightly regulated financial systems suffered less extreme crises in 2008-09, after controlling for the level of real GDP per capita. Do these empirical findings characterize other global downturns?

The panels of Table 7 are analogues to Table 6, for different worldwide downturns. After having grown for years at around 3.7\%, the world economy turned down sharply; in 1991, global output growth 
fell to $1.5 \%$. The downturn was particularly pronounced among the advanced economies, and persisted through 1992 (and indeed 1993). Accordingly, where Table 6 uses data for a cross-section of countries during the "Great Recession" of 2008-09, Table 7a examines the global slowdown of 1991-92. Another, more shallow, global slowdown occurred in 2001-02 when the growth of the world economy slowed to $2.3 \%$ after previously growing at 3.7\% (again, this event disproportionately hit richer economies).

Accordingly, Table 7b is an analogue for the slowdown of 2001-02. Both panels of Table 7 use the three variables that most successfully captured growth in Tables 5 and 6 , namely the current account/GDP ratio, the degree of credit market regulation, and the level of real GDP per capita (we interpret the latter as a control). In all cases, these variables are measured for the year before the worldwide slowdown occurred, and the estimation is done for the six different samples of countries examined in Table 5a.

The estimates of Table 7 show that even the best estimates gleaned from Tables 5 and 6 may not be particularly stable over time (even focusing on global recessions that are only clearly seen ex post). Countries with large current account deficits seemed to suffer more in the Great Recession, but not in the 2001-02 slowdown when the effect is usually negative (but insignificant). Even more strikingly, consider the single most robust result of the 2008-09 analysis, namely the negative and significant effect of the credit market regulation variable. For the two previous global recessions, the effect is often positive and significantly so in a number of the samples; it is never significantly negative. Such sample sensitivity reinforces our skepticism concerning the value of such exercises. Table A2 in the appendix provides some corroborating sensitivity analysis; it reveals that neither credit growth nor short-term external debt play consistently important and negative roles in predicting growth.

\section{Conclusion}

In our earlier research on early warning systems (Rose and Spiegel, 2010a, 2010b), we found that it was difficult to reliably link macroeconomic or financial indicators from 2006 or earlier to a 
variety of financial and real manifestations of the 2008 crisis. In this short paper, we show that this negative finding seems robust, in particular to a number of apparent successes in the recent literature. In particular, we examine the sensitivity of our findings to: a) new data available through the Spring of 2010; b) (seven) different measures of cross-country crisis intensity; c) (eight) different potential causes of the crisis that have worked for other researchers; d) (six) different country samples; and e) a different estimation strategy. Despite a broad search, we have been unable to find consistent strong linkages between pre-existing variables that are plausible causes of the Great Recession and the actual intensity of the recession. Our models just do not seem to fit the data well even "in sample" and the effects of our wide range of potential causes cannot be estimated with reasonable precision. Perhaps this is because crisis causes varied across countries. Perhaps "this time was different." Either explanation reinforces our skepticism about the feasibility of developing a forward-looking early warning system.

It is natural for economists to generalize from experiences of a few particularly salient countries to make generalizations, though it is often inappropriate. Our poor regression results are simply telling us that the pre-conditions for the crisis in the United States (or Iceland, or Latvia, ...) often do not describe other countries particularly well. Credit growth was high before 2008 in Australia, Canada, and South Africa, yet these countries seemed to have weathered the crisis well. Real housing prices actually fell in Japan, Germany and Portugal, yet these countries were hard hit. Since it is difficult to understand the cross-country incidence of the great recession even in retrospect, we are dubious about the potential for comparable "early warning" forecasting model going forward. 


\section{$\underline{\text { References }}$}

Adrian, Tobias and Hyun Song Shin (2008) “Financial Intermediaries, Financial Stability, and Monetary Policy" FRBNY Staff Report No. 346.

Berkmen, Pelin, Gaston Gelos, Robert Rennhack and James. P. Walsh (2009) "The Global Financial Crisis: Explaining Cross-Country Differences in the Output Impact" IMF Working Paper WP/09/280.

Blanchard, Olivier, Hamid Faruqee and Mitali Das (2010) "The Initial Impact of the Crisis on Emerging Market Countries" unpublished.

Claessens, Stijn, Giovanni Dell'Ariccia, Deniz Igan and Luc Laeven (2010) “Cross-Country Experiences and Policy Implications from the Global Financial Crisis" Economic Policy 62, 267-293.

Frankel, Jeffrey A. and George Saravelos (2010) "Are Leading Indicators of Financial Crises Useful for Assessing Country Vulnerability?" NBER Working Paper No. 16,047.

Giannone, Domenico, Michele Lenza and Lucrezia Reichlin (2010) “Market Freedom and the Global Recession" unpublished.

Goldberger, Arthur S. (1972) "Structural Equation Methods in the Social Sciences"

Econometrica, 40, 979-1001.

Lane, Philip R., and Gian Maria Milesi-Ferretti (2010) "The Cross-Country Incidence of the Global Crisis" unpublished.

Obstfeld, Maurice, Jay C. Shambaugh, and Alan M. Taylor (2009) "Financial Instability, Reserves, and Central Bank Swap Lines in the Panic of 2008" NBER Working Paper No. 14,826.

Rabe-Hesketh, Sophia, Anders Skrondal, and Andrew Pickles (2004) “GLLAMM Manual” UC Berkeley Biostatistics Working Paper 160.

Rose, Andrew K. and Mark M. Spiegel (2010a) “Cross-Country Causes and Consequences of the 2008 Crisis: Early Warning" Global Journal of Economics forthcoming.

Rose, Andrew K. and Mark M. Spiegel (2010b) “Cross-Country Causes and Consequences of the 2008 Crisis: International Linkages and American Exposure" Pacific Economic Review forthcoming. 
Figure 1: Comparison of 2008 and 2008-09 Data on Crisis Manifestations for MIMIC Model

\section{Four Crisis Manifestations}

2008 against 2008-09 Changes
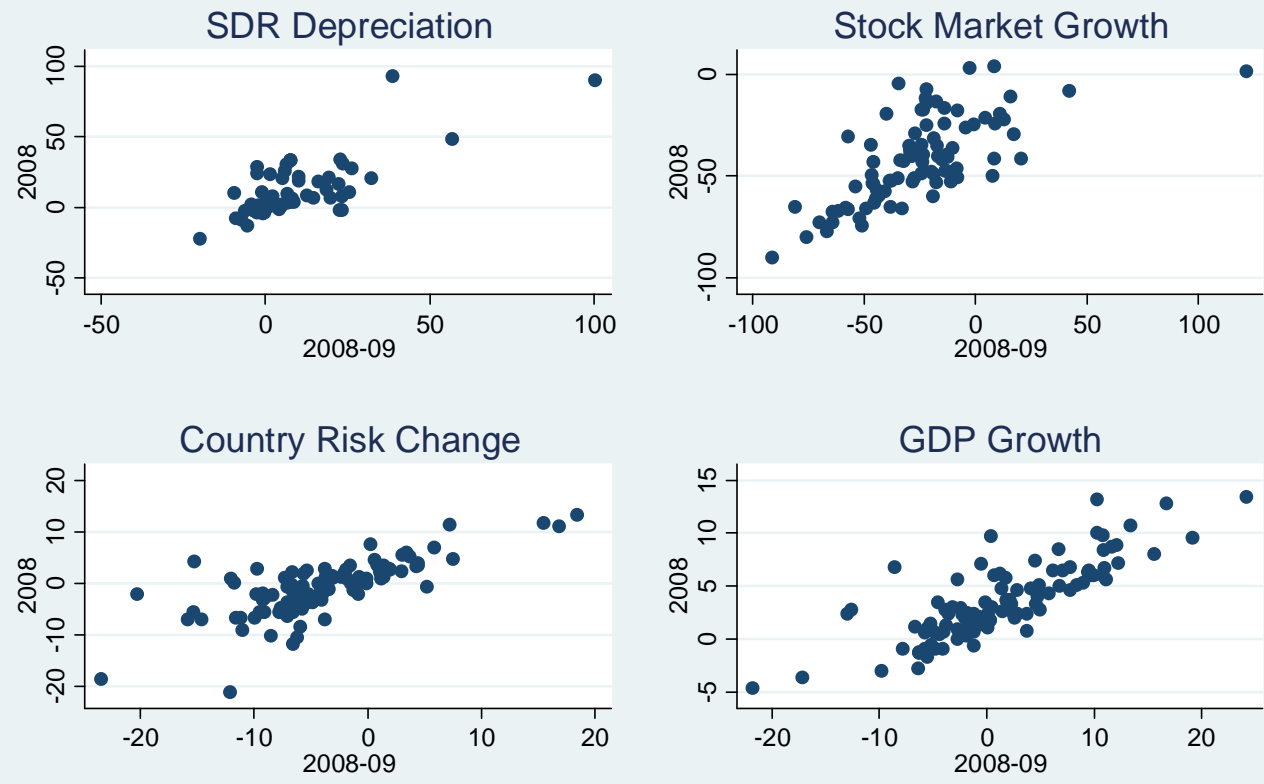

Figure 2: Comparison of Different Measures of the 2008-09 Crisis

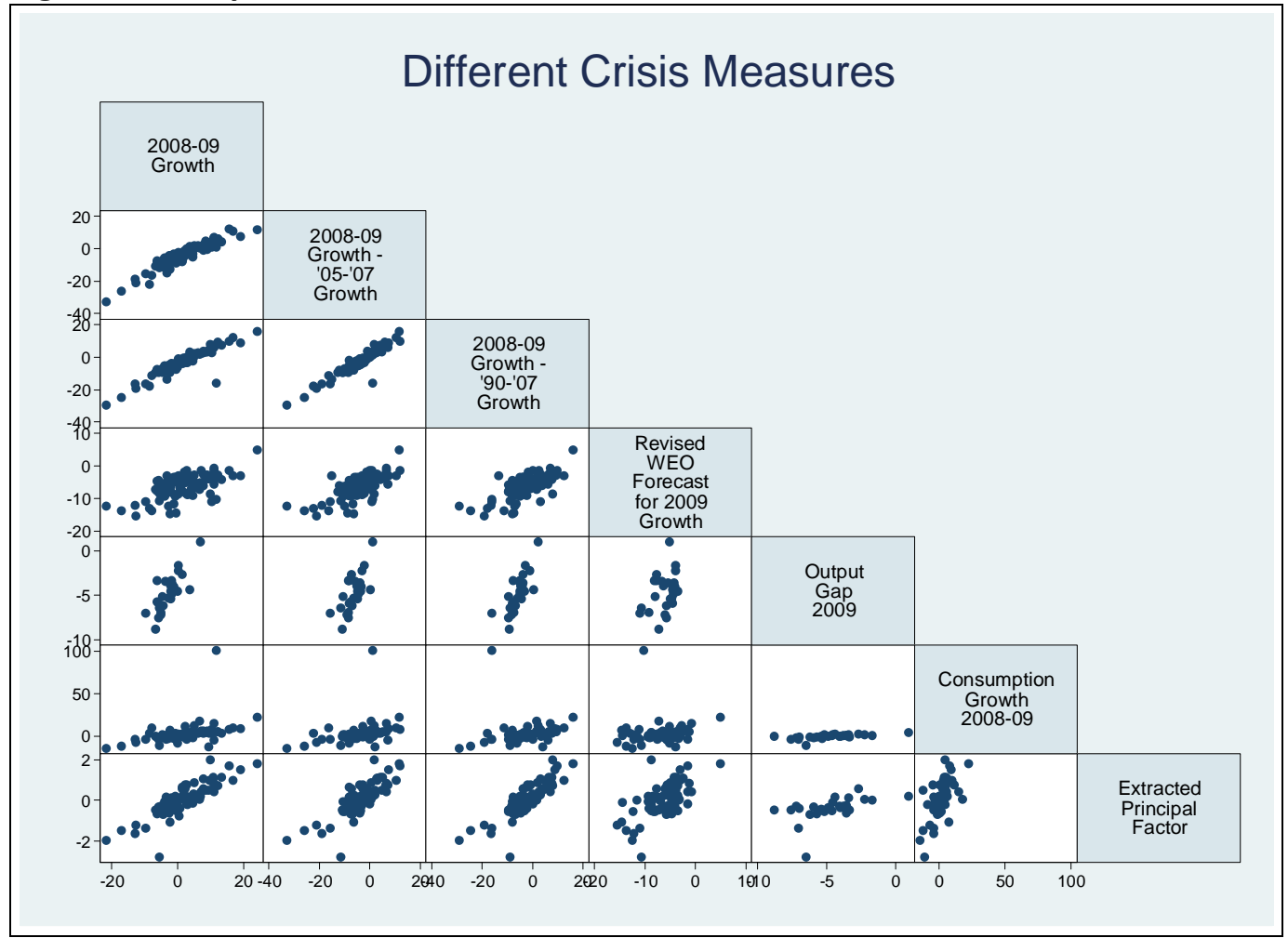


Figure 3: Bivariate Scatter-plots of 2008-09 Growth against Early Warning Indicators

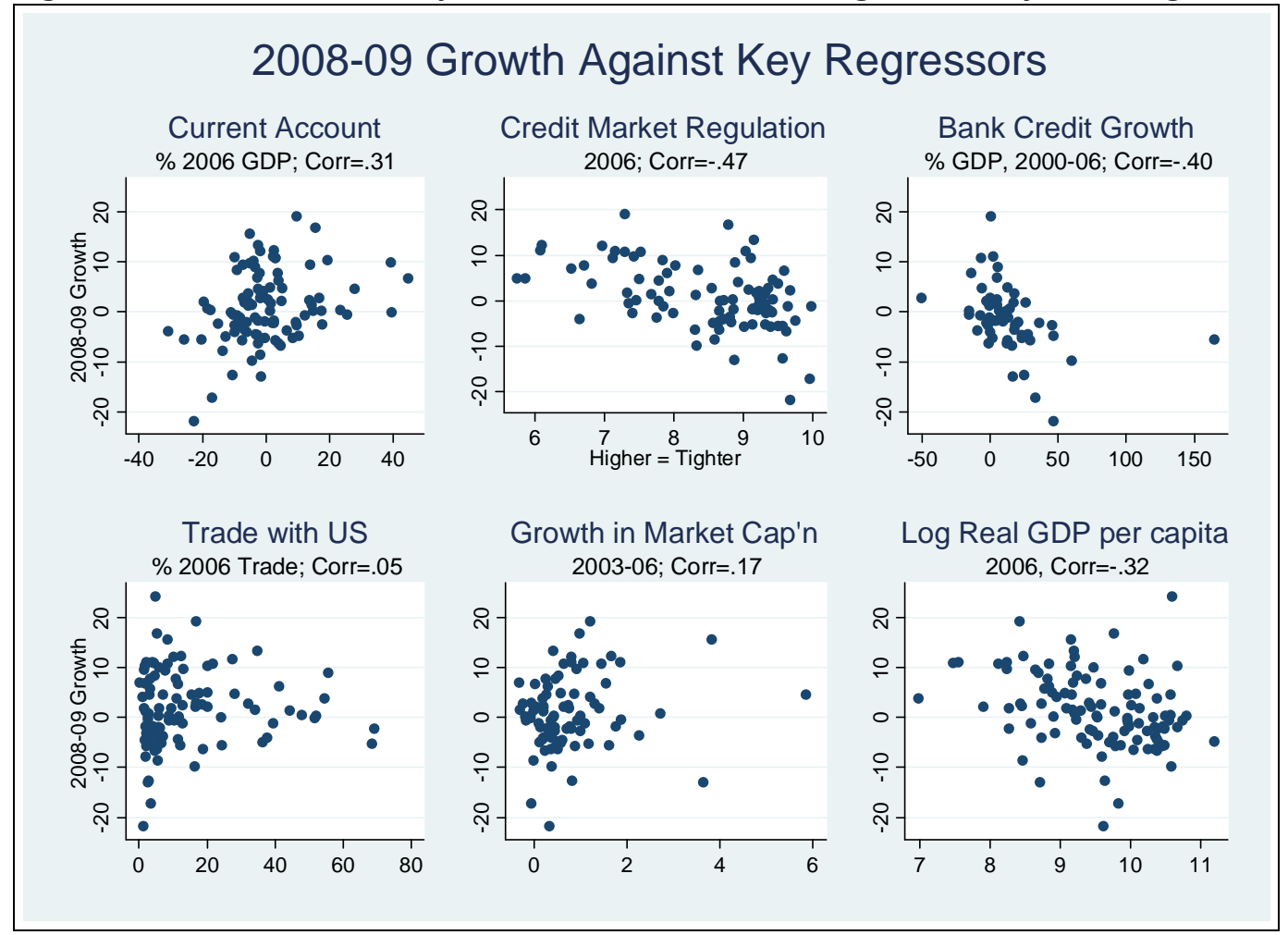

Figure 4: Searching for a Non-Linearity or Threshold

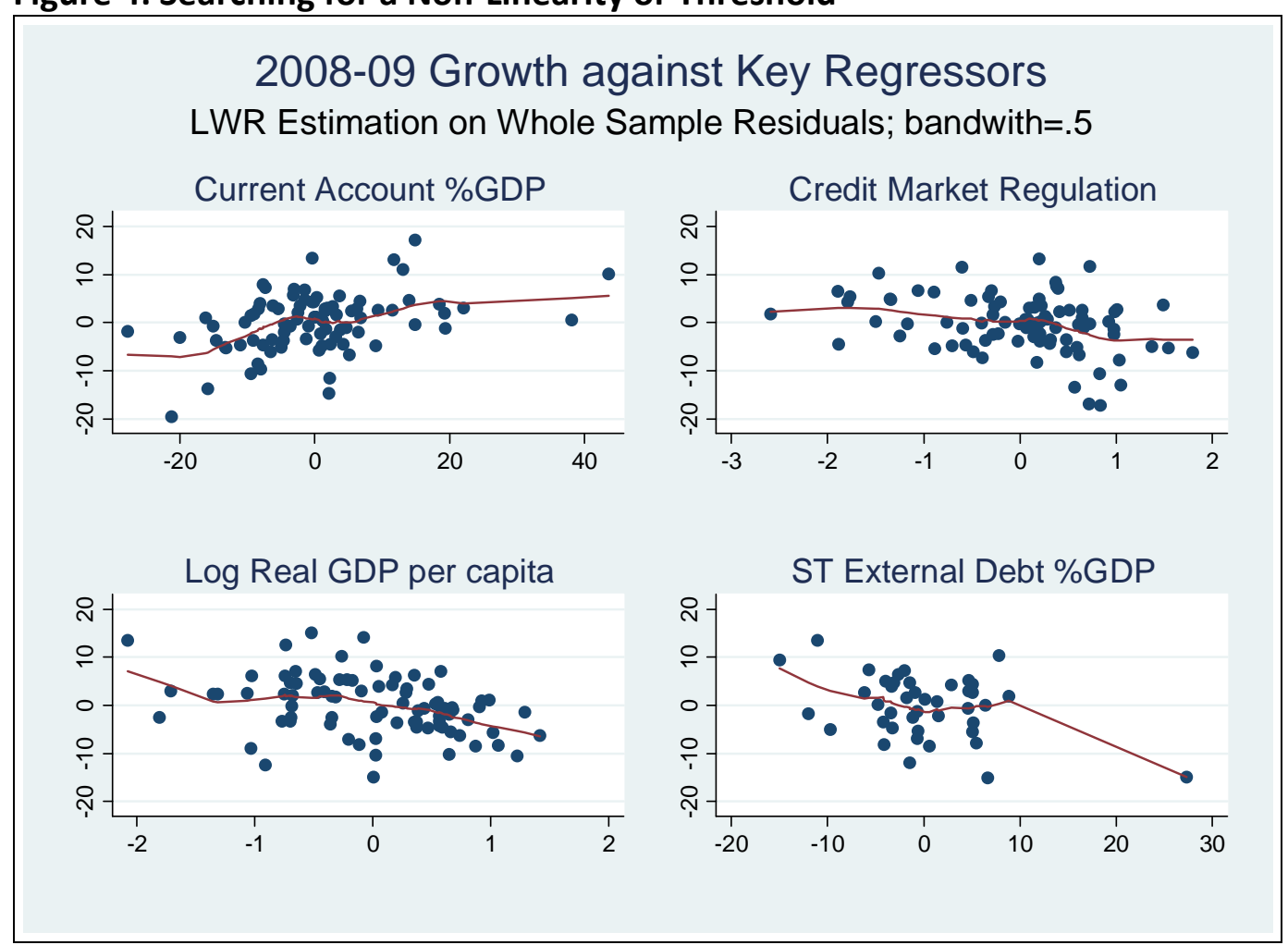


Table 1: Estimates from Multiple Indicator Multiple Cause Model, 2008-09 Crisis Manifestations

\begin{tabular}{|c|c|c|c|c|}
\hline $\begin{array}{l}\text { Log Real GDP per } \\
\text { capita, } 2006\end{array}$ & $\begin{array}{c}-16.4 * * \\
(3.9) \\
\end{array}$ & $\begin{array}{c}-12.9^{*} \\
(5.4) \\
\end{array}$ & $\begin{array}{l}-6.4 \\
(5.2) \\
\end{array}$ & $\begin{array}{c}-8.6 \\
(13.9) \\
\end{array}$ \\
\hline $\begin{array}{l}\text { Growth in Market } \\
\text { Capitalization } \\
2003-06\end{array}$ & $\begin{array}{c}-8.3 * * \\
(3.2)\end{array}$ & $\begin{array}{l}-8.9^{* *} \\
(3.45\end{array}$ & $\begin{array}{c}-10.7^{* *} \\
(3.2)\end{array}$ & $\begin{array}{l}-8.6 \\
(5.3)\end{array}$ \\
\hline $\begin{array}{l}\text { Trade with USA, \% } \\
\text { total } 2006 \text { trade }\end{array}$ & $\begin{array}{c}.32 \\
(.20)\end{array}$ & $\begin{array}{l}.36 \\
(.21)\end{array}$ & $\begin{array}{l}.61^{* *} \\
(.21)\end{array}$ & $\begin{array}{l}.25 \\
(.41)\end{array}$ \\
\hline $\begin{array}{l}\text { Current Account } \\
\% \text { GDP, } 2006\end{array}$ & & $\begin{array}{c}.2 \\
(.3) \\
\end{array}$ & $\begin{array}{l}.2 \\
(.3) \\
\end{array}$ & $\begin{array}{c}.1 \\
(1.1) \\
\end{array}$ \\
\hline $\begin{array}{l}\text { Credit Market } \\
\text { Regulation, } 2006\end{array}$ & & $\begin{array}{l}-2.0 \\
(3.4)\end{array}$ & $\begin{array}{c}2.0 \\
(3.1)\end{array}$ & $\begin{array}{l}-2.1 \\
(5.9)\end{array}$ \\
\hline $\begin{array}{l}\text { Growth in Bank } \\
\text { Credit \%GDP, } \\
2000-06\end{array}$ & & $\begin{array}{l}-.14 \\
(.11)\end{array}$ & $\begin{array}{c}-.23^{* *} \\
(.08)\end{array}$ & $\begin{array}{l}-.1 \\
(.4)\end{array}$ \\
\hline $\begin{array}{l}\text { Real House Price } \\
\text { growth, 2000-06 }\end{array}$ & & & $\begin{array}{l}-.01 \\
(.05) \\
\end{array}$ & \\
\hline $\begin{array}{l}\text { ST External Debt } \\
\% \text { GDP, } 2006\end{array}$ & & & & $\begin{array}{l}-.6 \\
(.9)\end{array}$ \\
\hline Observations & 81 & 75 & 43 & 38 \\
\hline
\end{tabular}

Coefficients, with standard error displayed in parentheses. Coefficients significantly different from zero at .05 (.01) significance level marked by one (two) asterisk(s). Each column represents MIMC estimation on cross-section.

Default: 4 consequences (2008-09 change in Stocks, 2008-09 Growth, 2-year change in Euromoney rating, 2008-09 SDR Exchange Rate change), fixed loading on stocks. Adaptive quadrature estimation.

Table 2: Comparing Different Measures of the Crisis: Correlation Coefficients

\begin{tabular}{|c|c|c|c|c|c|c|}
\hline & $\begin{array}{l}\text { 2008-09 } \\
\text { Growth }\end{array}$ & $\begin{array}{c}\text { 2008-09 } \\
\text { Growth } \\
\text { - '05-'07 } \\
\text { Growth }\end{array}$ & $\begin{array}{l}\text { 2008-09 } \\
\text { Growth } \\
\text { - '90-'07 } \\
\text { Growth }\end{array}$ & $\begin{array}{l}\text { Revised WEO } \\
2009 \text { Growth } \\
\text { Forecast }\end{array}$ & $\begin{array}{l}\text { Output } \\
\text { Gap } 2009\end{array}$ & $\begin{array}{l}\text { Consumption } \\
\text { Growth } \\
2008-09\end{array}$ \\
\hline $\begin{array}{l}\text { 2008-09 Growth } \\
\text { - '05-'07 Growth }\end{array}$ & .93 & & & & & \\
\hline $\begin{array}{l}\text { 2008-09 Growth } \\
\text { - '90-'07 Growth }\end{array}$ & .92 & .94 & & & & \\
\hline $\begin{array}{l}\text { Revised WEO } 2009 \\
\text { Growth Forecast }\end{array}$ & .60 & .69 & .69 & & & \\
\hline Output Gap 2009 & .78 & .71 & .77 & .35 & & \\
\hline $\begin{array}{l}\text { Consumption } \\
\text { Growth } \\
2008-09\end{array}$ & .43 & .36 & .14 & .08 & .61 & \\
\hline $\begin{array}{l}\text { Extracted Principal } \\
\text { Factor }\end{array}$ & .86 & .81 & .85 & .62 & .50 & .65 \\
\hline Observations & 106 & 99 & 99 & 102 & 28 & 93 \\
\hline
\end{tabular}


Table 3a: Effect of Exchange Rate Regime on Crisis Severity

\begin{tabular}{|l|c|c|c|c|c|c|}
\hline & All & $\begin{array}{c}\text { High } \\
\text { Income }\end{array}$ & $\begin{array}{c}\text { No } \\
\text { Advanced }\end{array}$ & $\begin{array}{c}\text { No } \\
\text { Oil }\end{array}$ & $\begin{array}{c}\text { No Fin'l } \\
\text { Centers }\end{array}$ & $\begin{array}{c}\text { No Poor, } \\
\text { Oil, or FCs }\end{array}$ \\
\hline 2008-09 & -1.42 & .51 & -1.79 & $-3.07^{*}$ & -1.62 & -2.29 \\
Growth & $(1.41)$ & $(1.92)$ & $(1.91)$ & $(1.48)$ & $(1.55)$ & $(2.01)$ \\
\hline 2008-09 Growth & -2.11 & -.25 & -2.50 & -3.21 & -2.42 & -3.54 \\
-'05-'07 Growth & $(1.46)$ & $(1.72)$ & $(1.99)$ & $(1.62)$ & $(1.60)$ & $(2.24)$ \\
\hline 2008-09 Growth & -2.08 & -.60 & -2.48 & -2.96 & -2.38 & -2.76 \\
-'90-'07 Growth & $(1.42)$ & $(1.81)$ & $(1.95)$ & $(1.53)$ & $(1.56)$ & $(2.10)$ \\
\hline Revised WEO 2009 & .16 & 1.15 & -.13 & -.39 & -.29 & -1.10 \\
Growth Forecast & $(.72)$ & $(.98)$ & $(.91)$ & $(.80)$ & $(.73)$ & $(.95)$ \\
\hline Output Gap & -.73 & -.62 & $n / a$ & -.73 & -.55 & -.55 \\
2009 & $(.71)$ & $(.70)$ & & $(.71)$ & $(.78)$ & $(.78)$ \\
\hline Consumption & .36 & 3.46 & -1.06 & -1.47 & .38 & -1.86 \\
Growth 2008-09 & $(2.39)$ & $(4.64)$ & $(2.73)$ & $(1.13)$ & $(2.62)$ & $(1.39)$ \\
\hline Extracted Principal & -.14 & .01 & -.17 & -.26 & -.22 & -.21 \\
Factor & $(.17)$ & $(.21)$ & $(.24)$ & $(.18)$ & $(.17)$ & $(.22)$ \\
\hline
\end{tabular}

Coefficients, with robust standard errors displayed in parentheses. Coefficients significantly different from zero at .05 (.01) significance level marked by one (two) asterisk(s). Each cell represents a different cross-country OLS regression, with regressand tabulated at left, over sample tabulated at top. Intercept and log real GDP per capita included throughout but not recorded. Dummy for 2007 de facto fixed exchange rate regime taken from Lane and Milesi-Ferretti (2010).

Table 3b: Effect of Current Account on Crisis Severity

\begin{tabular}{|l|c|c|c|c|c|c|}
\hline & All & $\begin{array}{c}\text { High } \\
\text { Income }\end{array}$ & $\begin{array}{c}\text { No } \\
\text { Advanced }\end{array}$ & $\begin{array}{c}\text { No } \\
\text { Oil }\end{array}$ & $\begin{array}{c}\text { No Fin'l } \\
\text { Centers }\end{array}$ & $\begin{array}{c}\text { No Poor, } \\
\text { Oil, or FCs }\end{array}$ \\
\hline $2008-09$ & $.23^{* *}$ & $.21^{* *}$ & $.26^{* *}$ & $.25^{* *}$ & $.22^{* *}$ & $.27^{*}$ \\
Growth & $(.05)$ & $(.06)$ & $(.06)$ & $(.07)$ & $(.06)$ & $(.12)$ \\
\hline 2008-09 Growth & $.20^{* *}$ & $.17^{*}$ & $.26^{* *}$ & $.26^{* *}$ & $.21^{* *}$ & $.33^{*}$ \\
-'05-07 Growth $^{\prime}$ & $(.06)$ & $(.07)$ & $(.08)$ & $(.09)$ & $(.07)$ & $(.14)$ \\
\hline 2008-09 Growth & $.21^{* *}$ & $.17^{*}$ & $.26^{* *}$ & $.23^{*}$ & $.22^{* *}$ & .28 \\
-'90-'07 Growth & $(.06)$ & $(.07)$ & $(.08)$ & $(.09)$ & $(.07)$ & $(.14)$ \\
\hline Revised WEO 2009 & .02 & .02 & .05 & .01 & .02 & .01 \\
Growth Forecast & $(.03)$ & $(.03)$ & $(.03)$ & $(.05)$ & $(.03)$ & $(.07)$ \\
\hline Output Gap & .07 & $.07^{*}$ & $\mathrm{n} / \mathrm{a}$ & .07 & .04 & .04 \\
2009 & $(.04)$ & $(.03)$ & & $(.04)$ & $(.07)$ & $(.07)$ \\
\hline Consumption & $.18^{*}$ & .16 & $.20^{*}$ & $.25^{* *}$ & $.19^{*}$ & $.26^{* *}$ \\
Growth 2008-09 & $(.07)$ & $(.11)$ & $(.09)$ & $(.07)$ & $(.08)$ & $(.09)$ \\
\hline Extracted Principal & $.03^{* *}$ & $.02^{*}$ & $.03^{* *}$ & $.03^{* *}$ & $.02^{* *}$ & .02 \\
Factor & $(.01)$ & $(.01)$ & $(.01)$ & $(.01)$ & $(.01)$ & $(.02)$ \\
\hline
\end{tabular}

Coefficients, with robust standard errors displayed in parentheses. Coefficients significantly different from zero at .05 (.01) significance level marked by one (two) asterisk(s). Each cell represents a different cross-country OLS regression, with regressand tabulated at left, over sample tabulated at top. Intercept and log real GDP per capita included throughout but not recorded. 2006 current account as percentage of GDP taken from WDI. 
Table 3c: Effect of Trading Partner Growth on Crisis Severity

\begin{tabular}{|l|c|c|c|c|c|c|}
\hline & All & $\begin{array}{c}\text { High } \\
\text { Income }\end{array}$ & $\begin{array}{c}\text { No } \\
\text { Advanced }\end{array}$ & $\begin{array}{c}\text { No } \\
\text { Oil }\end{array}$ & $\begin{array}{c}\text { No Fin'l } \\
\text { Centers }\end{array}$ & $\begin{array}{c}\text { No Poor, } \\
\text { Oil, or FCs }\end{array}$ \\
\hline 2008-09 & 14.8 & 211.7 & -33.0 & -51.6 & -12.6 & -21.9 \\
Growth & $(65.4)$ & $(88.1)$ & $(87.1)$ & $(64.4)$ & $(85.1)$ & $(169.0)$ \\
\hline 2008-09 Growth & -46.9 & 156.3 & -83.6 & -106.9 & -79.6 & -89.4 \\
-'05-'07 Growth & $(71.7)$ & $(89.3)$ & $(99.0)$ & $(71.8)$ & $(92.8)$ & $(194.9)$ \\
\hline 2008-09 Growth & -52.9 & 141.2 & -95.6 & -99.4 & -89.0 & -98.3 \\
-'90-'07 Growth & $(68.2)$ & $(86.2)$ & $(92.1)$ & $(65.3)$ & $(88.3)$ & $(179.2)$ \\
\hline Revised WEO 2009 & 73.9 & -66.8 & -58.7 & $-110.2^{* *}$ & $-66.6 *$ & -85.8 \\
Growth Forecast & $(26.9)$ & $(42.9)$ & $(34.2)$ & $(27.4)$ & $(32.1)$ & $(71.5)$ \\
\hline Output Gap & 29.2 & 16.2 & $\mathrm{n} / \mathrm{a}$ & 29.2 & 11.1 & 11.1 \\
2009 & $(43.1)$ & $(41.5)$ & & $(43.1)$ & $(48.7)$ & $(48.7)$ \\
\hline Consumption & 45.6 & 245.2 & -35.1 & -63.5 & 76.3 & -95.5 \\
Growth 2008-09 & $(85.2)$ & $(149.8)$ & $(93.5)$ & $(53.4)$ & $(124.6)$ & $(117.9)$ \\
\hline Extracted Principal & 1.0 & 20.2 & -14.4 & -1.7 & -10.9 & -12.5 \\
Factor & $(8.6)$ & $(6.5)$ & $(14.7)$ & $(9.5)$ & $(12.4)$ & $(16.5)$ \\
\hline
\end{tabular}

Coefficients, with robust standard errors displayed in parentheses. Coefficients significantly different from zero at .05 (.01) significance level marked by one (two) asterisk(s). Each cell represents a different cross-country OLS regression, with regressand tabulated at left, over sample tabulated at top. Intercept and log real GDP per capita included throughout but not recorded. Average growth in trading partners' 2005-07 GDP taken from Lane and Milesi-Ferretti (2010).

Table 3d: Effect of Credit Market Regulation on Crisis Severity

\begin{tabular}{|c|c|c|c|c|c|c|}
\hline & All & $\begin{array}{c}\text { High } \\
\text { Income }\end{array}$ & $\begin{array}{c}\text { No } \\
\text { Advanced }\end{array}$ & $\begin{array}{l}\text { No } \\
\text { Oil }\end{array}$ & $\begin{array}{l}\text { No Fin'l } \\
\text { Centers }\end{array}$ & $\begin{array}{l}\text { No Poor, } \\
\text { Oil, or FCs }\end{array}$ \\
\hline $\begin{array}{l}\text { 2008-09 } \\
\text { Growth }\end{array}$ & $\begin{array}{c}-2.38^{* *} \\
(.68)\end{array}$ & $\begin{array}{l}-1.15 \\
(1.37)\end{array}$ & $\begin{array}{c}-2.95 * * \\
(.82)\end{array}$ & $\begin{array}{c}-2.76^{* *} \\
(.77)\end{array}$ & $\begin{array}{c}-2.56 * * \\
(.71)\end{array}$ & $\begin{array}{l}-2.22 \\
(1.12)\end{array}$ \\
\hline $\begin{array}{l}\text { 2008-09 Growth } \\
\text { - '05-'07 Growth }\end{array}$ & $\begin{array}{c}-2.54^{* *} \\
(.78)\end{array}$ & $\begin{array}{l}-1.30 \\
(1.56)\end{array}$ & $\begin{array}{c}-3.10^{* *} \\
(.91)\end{array}$ & $\begin{array}{c}-2.84^{* *} \\
(.91)\end{array}$ & $\begin{array}{c}-2.75^{* *} \\
(.81)\end{array}$ & $\begin{array}{l}-2.51 \\
(1.27)\end{array}$ \\
\hline $\begin{array}{l}\text { 2008-09 Growth } \\
\text {-'90-'07 Growth }\end{array}$ & $\begin{array}{c}-2.72^{* *} \\
(.74)\end{array}$ & $\begin{array}{l}-1.17 \\
(1.57)\end{array}$ & $\begin{array}{c}-3.38^{* *} \\
(.88)\end{array}$ & $\begin{array}{c}-3.07^{* *} \\
(.85)\end{array}$ & $\begin{array}{c}-2.97^{* *} \\
(.75)\end{array}$ & $\begin{array}{l}-2.82^{*} \\
(1.24)\end{array}$ \\
\hline $\begin{array}{l}\text { Revised WEO } 2009 \\
\text { Growth Forecast }\end{array}$ & $\begin{array}{c}-1.02^{* *} \\
(.34)\end{array}$ & $\begin{array}{l}-.21 \\
(.72)\end{array}$ & $\begin{array}{c}-1.33^{* *} \\
(.36)\end{array}$ & $\begin{array}{l}-.97^{*} \\
(.38)\end{array}$ & $\begin{array}{c}-1.13^{* *} \\
(.35)\end{array}$ & $\begin{array}{l}-.89 \\
(.53)\end{array}$ \\
\hline $\begin{array}{l}\text { Output Gap } \\
2009\end{array}$ & $\begin{array}{l}-.87 \\
(.49)\end{array}$ & $\begin{array}{l}-.55 \\
(.44)\end{array}$ & $\mathrm{n} / \mathrm{a}$ & $\begin{array}{l}-.87 \\
(.49)\end{array}$ & $\begin{array}{c}-1.07^{*} \\
(.50)\end{array}$ & $\begin{array}{c}-1.07^{*} \\
(.50)\end{array}$ \\
\hline $\begin{array}{l}\text { Consumption } \\
\text { Growth 2008-09 }\end{array}$ & $\begin{array}{c}-1.63^{* *} \\
(.61)\end{array}$ & $\begin{array}{c}-.77 \\
(1.17) \\
\end{array}$ & $\begin{array}{c}-1.93^{*} \\
(.74)\end{array}$ & $\begin{array}{c}-1.46^{*} \\
(.63)\end{array}$ & $\begin{array}{c}-1.60^{*} \\
(.63)\end{array}$ & $\begin{array}{l}-1.46 \\
(.74)\end{array}$ \\
\hline $\begin{array}{l}\text { Extracted Principal } \\
\text { Factor }\end{array}$ & $\begin{array}{c}-.21^{* *} \\
(.07)\end{array}$ & $\begin{array}{l}-.08 \\
(.14)\end{array}$ & $\begin{array}{c}.27^{* *} \\
(.08)\end{array}$ & $\begin{array}{c}.22 * * \\
(.07)\end{array}$ & $\begin{array}{c}.21 * * \\
(.07)\end{array}$ & $\begin{array}{l}-.20 \\
(.10)\end{array}$ \\
\hline
\end{tabular}

Coefficients, with robust standard errors displayed in parentheses. Coefficients significantly different from zero at .05 (.01) significance level marked by one (two) asterisk(s). Each cell represents a different cross-country OLS regression, with regressand tabulated at left, over sample tabulated at top. Intercept and log real GDP per capita included throughout but not recorded. 2006 Credit Market Regulation score taken from Frazer institutes "Economic Freedom of the World" database, available from Heritage Foundation; higher score corresponds to tighter regulation. 
Table 3e: Effect of Short-Term External Debt on Crisis Severity

\begin{tabular}{|l|c|c|c|c|c|c|}
\hline & All & $\begin{array}{c}\text { High } \\
\text { Income }\end{array}$ & $\begin{array}{c}\text { No } \\
\text { Advanced }\end{array}$ & $\begin{array}{c}\text { No } \\
\text { Oil }\end{array}$ & $\begin{array}{c}\text { No Fin'l } \\
\text { Centers }\end{array}$ & $\begin{array}{c}\text { No Poor, } \\
\text { Oil, or FCs }\end{array}$ \\
\hline $\begin{array}{l}\text { 2008-09 } \\
\text { Growth }\end{array}$ & $\begin{array}{c}-.27^{* *} \\
(.10)\end{array}$ & $\mathrm{n} / \mathrm{a}$ & $\begin{array}{c}-.27^{* *} \\
(.10)\end{array}$ & $\begin{array}{c}-.30^{* *} \\
(.11)\end{array}$ & $\begin{array}{c}-.27^{* *} \\
(.10)\end{array}$ & $\begin{array}{c}-.25^{*} \\
(.12)\end{array}$ \\
\hline $\begin{array}{l}\text { 2008-09 Growth } \\
\text {-'05-'07 Growth }\end{array}$ & $\begin{array}{c}-.32^{* *} \\
(.12)\end{array}$ & $\mathrm{n} / \mathrm{a}$ & $\begin{array}{c}-.32^{* *} \\
(.12)\end{array}$ & $\begin{array}{c}-.35^{* *} \\
(.12)\end{array}$ & $\begin{array}{c}-.32^{* *} \\
(.12)\end{array}$ & $-.21^{*}$ \\
\hline 2008-09 Growth & $-.28^{*}$ & $\mathrm{n} / \mathrm{a}$ & $-.28^{*}$ & $-.30^{*}$ & $-.28^{*}$ & -.24 \\
-'90-'07 Growth & $(.12)$ & & $(.12)$ & $(.12)$ & $(.12)$ & $(.13)$ \\
\hline Revised WEO 2009 & $-.12^{* *}$ & $\mathrm{n} / \mathrm{a}$ & $-.12^{* *}$ & $-.11^{* *}$ & $-.12^{* *}$ & $-.09^{*}$ \\
Growth Forecast & $(.03)$ & & $(.03)$ & $(.03)$ & $(.03)$ & $(.04)$ \\
\hline Output Gap & $\mathrm{n} / \mathrm{a}$ & $\mathrm{n} / \mathrm{a}$ & $\mathrm{n} / \mathrm{a}$ & $\mathrm{n} / \mathrm{a}$ & $\mathrm{n} / \mathrm{a}$ & $\mathrm{n} / \mathrm{a}$ \\
2009 & & & & & & \\
\hline Consumption & $-.12^{* *}$ & $\mathrm{n} / \mathrm{a}$ & -.11 & -.10 & -.11 & -.04 \\
Growth 2008-09 & $(.03)$ & & $(.15)$ & $(.15)$ & $(.15)$ & $(.16)$ \\
\hline Extracted Principal & $-.04^{* *}$ & $\mathrm{n} / \mathrm{a}$ & $-.04^{* *}$ & $-.04^{* *}$ & $-.04^{* *}$ & -.03 \\
Factor & $(.01)$ & & $(.01)$ & $(.01)$ & $(.01)$ & $(.01)$ \\
\hline
\end{tabular}

Coefficients, with robust standard errors displayed in parentheses. Coefficients significantly different from zero at .05 (.01) significance level marked by one (two) asterisk(s). Each cell represents a different cross-country OLS regression, with regressand tabulated at left, over sample tabulated at top. Intercept and log real GDP per capita included throughout but not recorded. Short Term External Debt in 2006 measured as percentage of GDP, taken from WDI.

Table 3f: Effect of Housing Price Change on Crisis Severity

\begin{tabular}{|l|c|c|c|c|c|c|}
\hline & All & $\begin{array}{c}\text { High } \\
\text { Income }\end{array}$ & $\begin{array}{c}\text { No } \\
\text { Advanced }\end{array}$ & $\begin{array}{c}\text { No } \\
\text { Oil }\end{array}$ & $\begin{array}{c}\text { No Fin'l } \\
\text { Centers }\end{array}$ & $\begin{array}{c}\text { No Poor, } \\
\text { Oil, or FCs }\end{array}$ \\
\hline 2008-09 & $-.06^{* *}$ & $-.04^{*}$ & $-.07^{*}$ & $-.06^{* *}$ & $-.06^{* *}$ & $-.06^{*}$ \\
Growth & $(.02)$ & $(.02)$ & $(.02)$ & $(.02)$ & $(.02)$ & $(.02)$ \\
\hline 2008-09 Growth & $-.08^{* *}$ & $-.06^{*}$ & $-.09^{* *}$ & $-.08^{* *}$ & $-.08^{* *}$ & $-.07^{*}$ \\
-'05-'07 Growth & $(.02)$ & $(.02)$ & $(.02)$ & $(.02)$ & $(.02)$ & $(.03)$ \\
\hline 2008-09 Growth & $-.07^{* *}$ & $-.06^{*}$ & $-.08^{* *}$ & $-.07^{* *}$ & $-.07^{* *}$ & $-.07^{*}$ \\
-'90-'07 Growth & $(.02)$ & $(.02)$ & $(.02)$ & $(.02)$ & $(.02)$ & $(.03)$ \\
\hline Revised WEO 2009 & $-.02^{* *}$ & -.02 & $-.02^{*}$ & $-.02^{*}$ & $-.02^{*}$ & -.02 \\
Growth Forecast & $(.01)$ & $(.01)$ & $(.01)$ & $(.01)$ & $(.01)$ & $(.01)$ \\
\hline Output Gap & -.00 & -.01 & $\mathrm{n} / \mathrm{a}$ & -.00 & .00 & .00 \\
2009 & $(.01)$ & $(.01)$ & & $(.01)$ & $(.01)$ & $(.01)$ \\
\hline Consumption & $-.05^{* *}$ & $-.04^{* *}$ & $-.04^{*}$ & $-.05^{* *}$ & $-.04^{* *}$ & $-.04^{* *}$ \\
Growth 2008-09 & $(.01)$ & $(.01)$ & $(.01)$ & $(.01)$ & $(.01)$ & $(.01)$ \\
\hline Extracted Principal & $-.007^{* *}$ & $-.005^{* *}$ & $-.007^{* *}$ & -.007 & $-.006^{* *}$ & $-.005^{*}$ \\
Factor & $(.002)$ & $(.002)$ & $(.002)$ & $(.002)$ & $(.002)$ & $(.002)$ \\
\hline
\end{tabular}

Coefficients, with robust standard errors displayed in parentheses. Coefficients significantly different from zero at .05 (.01) significance level marked by one (two) asterisk(s). Each cell represents a different cross-country OLS regression, with regressand tabulated at left, over sample tabulated at top. Intercept and log real GDP per capita included throughout but not recorded. Real housing price appreciation 2000-06 taken from Claessens et al (2010). 
Table 3g: Effect of Growth in Bank Credit on Crisis Severity

\begin{tabular}{|l|c|c|c|c|c|c|}
\hline & All & $\begin{array}{c}\text { High } \\
\text { Income }\end{array}$ & $\begin{array}{c}\text { No } \\
\text { Advanced }\end{array}$ & $\begin{array}{c}\text { No } \\
\text { Oil }\end{array}$ & $\begin{array}{c}\text { No Fin'l } \\
\text { Centers }\end{array}$ & $\begin{array}{c}\text { No Poor, } \\
\text { Oil, or FCs }\end{array}$ \\
\hline 2008-09 & $-.07^{* *}$ & $-.07^{* *}$ & $-.11^{* *}$ & $-.06^{*}$ & $-.09^{* *}$ & -.07 \\
Growth & $(.02)$ & $(.03)$ & $(.04)$ & $(.03)$ & $(.03)$ & $(.04)$ \\
\hline 2008-09 Growth & $-.06^{* *}$ & $-.06^{*}$ & $-.11^{*}$ & -.05 & $-.08^{*}$ & -.07 \\
-'05-'07 Growth & $(.02)$ & $(.02)$ & $(.05)$ & $(.03)$ & $(.03)$ & $(.05)$ \\
\hline 2008-09 Growth & $-.06^{*}$ & -.05 & $-.11^{*}$ & -.05 & $-.08^{*}$ & -.08 \\
-'90-07 Growth & $(.02)$ & $(.02)$ & $(.04)$ & $(.03)$ & $(.03)$ & $(.05)$ \\
\hline Revised WEO 2009 & -.01 & -.02 & -.02 & -.01 & -.01 & -.01 \\
Growth Forecast & $(.01)$ & $(.01)$ & $(.02)$ & $(.01)$ & $(.02)$ & $(.02)$ \\
\hline Output Gap & $-.01^{*}$ & $-.01^{*}$ & $\mathrm{n} / \mathrm{a}$ & $-.01^{*}$ & -.02 & -.02 \\
2009 & $(.01)$ & $(.01)$ & & $(.01)$ & $(.01)$ & $(.01)$ \\
\hline Consumption & $-.11^{*}$ & -.14 & -.15 & $-.06^{* *}$ & -.13 & -.07 \\
Growth 2008-09 & $(.05)$ & $(.08)$ & $(.10)$ & $(.01)$ & $(.08)$ & $(.03)$ \\
\hline Extracted Principal & $-.011^{* *}$ & $-.011^{* *}$ & $-.014^{* *}$ & $-.010^{* *}$ & $-.010^{* *}$ & -.007 \\
Factor & $(.002)$ & $(.002)$ & $(.004)$ & $(.002)$ & $(.003)$ & $(.005)$ \\
\hline
\end{tabular}

Coefficients, with robust standard errors displayed in parentheses. Coefficients significantly different from zero at .05 (.01) significance level marked by one (two) asterisk(s). Each cell represents a different cross-country OLS regression, with regressand tabulated at left, over sample tabulated at top. Intercept and log real GDP per capita included throughout but not recorded. Difference in Bank Credit as percentage of GDP between 2000 and 2006, taken from WDI.

Table 3h: Effect of Bank Credit on Crisis Severity

\begin{tabular}{|l|c|c|c|c|c|c|}
\hline & All & $\begin{array}{c}\text { High } \\
\text { Income }\end{array}$ & $\begin{array}{c}\text { No } \\
\text { Advanced }\end{array}$ & $\begin{array}{c}\text { No } \\
\text { Oil }\end{array}$ & $\begin{array}{c}\text { No Fin'l } \\
\text { Centers }\end{array}$ & $\begin{array}{c}\text { No Poor, } \\
\text { Oil, or FCs }\end{array}$ \\
\hline $2008-09$ & -.02 & $-.05^{* *}$ & -.01 & .01 & -.01 & .02 \\
Growth & $(.01)$ & $(.01)$ & $(.02)$ & $(.01)$ & $(.01)$ & $(.02)$ \\
\hline 2008-09 Growth & .00 & -.03 & .01 & $.03^{*}$ & .01 & $.03^{*}$ \\
-'05-'07 Growth $^{\prime}$ & $(.01)$ & $(.01)$ & $(.02)$ & $(.01)$ & $(.01)$ & $(.02)$ \\
\hline 2008-09 Growth & -.00 & -.02 & .01 & .02 & .01 & .02 \\
-'90-'07 Growth & $(.01)$ & $(.02)$ & $(.02)$ & $(.01)$ & $(.01)$ & $(.01)$ \\
\hline Revised WEO 2009 & .01 & -.00 & .01 & $.02^{*}$ & $.01^{*}$ & $.02^{*}$ \\
Growth Forecast & $(.01)$ & $(.01)$ & $(.01)$ & $(.01)$ & $(.01)$ & $(.01)$ \\
\hline Output Gap & .00 & .00 & $\mathrm{n} / \mathrm{a}$ & .00 & .01 & .01 \\
2009 & $(.01)$ & $(.01)$ & & $(.01)$ & $(.01)$ & $(.01)$ \\
\hline Consumption & -.06 & -.11 & -.07 & -.00 & -.06 & .01 \\
Growth 2008-09 & $(.04)$ & $(.07)$ & $(.07)$ & $(.01)$ & $(.04)$ & $(.01)$ \\
\hline Extracted Principal & -.002 & $-.005^{*}$ & .001 & .001 & -.000 & .003 \\
Factor & $(.002)$ & $(.002)$ & $(.003)$ & $(.002)$ & $(.002)$ & $(.002)$ \\
\hline
\end{tabular}

Coefficients, with robust standard errors displayed in parentheses. Coefficients significantly different from zero at .05 (.01) significance level marked by one (two) asterisk(s). Each cell represents a different cross-country OLS regression, with regressand tabulated at left, over sample tabulated at top. Intercept and log real GDP per capita included throughout but not recorded. Domestic Bank Credit to the Private Sector as percentage of GDP in 2006, taken from WDI. 
Table 3i: Effect of International Reserves on Crisis Severity

\begin{tabular}{|l|c|c|c|c|c|c|}
\hline & All & $\begin{array}{c}\text { High } \\
\text { Income }\end{array}$ & $\begin{array}{c}\text { No } \\
\text { Advanced }\end{array}$ & $\begin{array}{c}\text { No } \\
\text { Oil }\end{array}$ & $\begin{array}{c}\text { No Fin'l } \\
\text { Centers }\end{array}$ & $\begin{array}{c}\text { No Poor, } \\
\text { Oil, or FCs }\end{array}$ \\
\hline 2008-09 & $.068^{*}$ & .068 & .066 & $.075^{*}$ & .066 & .007 \\
Growth & $(.028)$ & $(.042)$ & $(.045)$ & $(.036)$ & $(.036)$ & $(.075)$ \\
\hline 2008-09 Growth & .029 & -.015 & .057 & .028 & .045 & .017 \\
-'05-'07 Growth & $(.026)$ & $(.022)$ & $(.041)$ & $(.033)$ & $(.033)$ & $(.080)$ \\
\hline 2008-09 Growth & .025 & -.019 & .035 & .016 & .032 & -.028 \\
-'90-'07 Growth & $(.031)$ & $(.022)$ & $(.053)$ & $(.029)$ & $(.044)$ & $(.071)$ \\
\hline Revised WEO 2009 & $-.047^{*}$ & $-.065^{* *}$ & -.034 & $-.054^{*}$ & -.042 & -.051 \\
Growth Forecast & $(.019)$ & $(.022)$ & $(.027)$ & $(.023)$ & $(.024)$ & $(.050)$ \\
\hline Output Gap & .082 & .067 & $\mathrm{n} / \mathrm{a}$ & .082 & .082 & .082 \\
2009 & $(.052)$ & $(.051)$ & & $.052)$ & $(.052)$ & $(.052)$ \\
\hline Consumption & .073 & .104 & .066 & $.039 *$ & .115 & .038 \\
Growth 2008-09 & $(.049)$ & $(.127)$ & $(.059)$ & $(.019)$ & $(.083)$ & $(.040)$ \\
\hline Extracted Principal & .007 & $.007^{* *}$ & .006 & .0003 & .007 & -.003 \\
Factor & $(.005)$ & $(.002)$ & $(.010)$ & $(.005)$ & $(.008)$ & $(.010)$ \\
\hline
\end{tabular}

Coefficients, with robust standard errors displayed in parentheses. Coefficients significantly different from zero at .05 (.01) significance level marked by one (two) asterisk(s). Each cell represents a different cross-country OLS regression, with regressand tabulated at left, over sample tabulated at top. Intercept and log real GDP per capita included throughout but not recorded. International reserves (without gold) as percentage of $2006 \mathrm{GDP}$, taken from WDI. 
Table 4: The Effect of Using Different Crisis Measures (Regressands)

\begin{tabular}{|c|c|c|c|c|c|c|c|c|}
\hline $\begin{array}{l}\text { Dependent } \\
\text { Variable: }\end{array}$ & $\begin{array}{c}\text { Current } \\
\text { Account } \\
\% \text { GDP, } \\
2006\end{array}$ & $\begin{array}{c}\text { Credit } \\
\text { Market } \\
\text { Regulation, } \\
2006\end{array}$ & $\begin{array}{c}\text { Bank } \\
\text { Credit } \\
\text { Growth } \\
\text { \%GDP, } \\
\text { 2000-06 }\end{array}$ & $\begin{array}{l}\text { US Trade } \\
\text { \%Trade, } \\
2006\end{array}$ & $\begin{array}{c}\text { Growth in } \\
\text { Market } \\
\text { Capitalization } \\
\text { 2003-06 }\end{array}$ & $\begin{array}{l}\text { Log Real } \\
\text { GDP per } \\
\text { capita, } \\
2006\end{array}$ & $\mathrm{R}^{2}$ & Obs \\
\hline $\begin{array}{l}\text { 2008-09 } \\
\text { Growth }\end{array}$ & $\begin{array}{l}.22 * * \\
(.08) \\
\end{array}$ & $\begin{array}{c}-2.01 * * \\
(.70)\end{array}$ & $\begin{array}{l}-.012 \\
(.025)\end{array}$ & $\begin{array}{l}-.002 \\
(.046)\end{array}$ & $\begin{array}{c}.85 \\
(.99) \\
\end{array}$ & $\begin{array}{c}-3.19 * * \\
(.1 .21)\end{array}$ & .41 & 75 \\
\hline $\begin{array}{l}\text { 2008-09 } \\
\text { Growth - } \\
\text { '05-'07 Growth }\end{array}$ & $\begin{array}{c}.15 \\
(.09)\end{array}$ & $\begin{array}{c}-2.30 * * \\
(.84)\end{array}$ & $\begin{array}{l}-.027 \\
(.024)\end{array}$ & $\begin{array}{c}.021 \\
(.053)\end{array}$ & $\begin{array}{c}.80 \\
(1.08)\end{array}$ & $\begin{array}{l}-1.52 \\
(1.52)\end{array}$ & .29 & 74 \\
\hline $\begin{array}{l}\text { 2008-09 } \\
\text { Growth - } \\
\text { '90-'07 Growth }\end{array}$ & $\begin{array}{l}.17^{*} \\
(.08)\end{array}$ & $\begin{array}{c}-2.50 * * \\
(.77)\end{array}$ & $\begin{array}{l}-.021 \\
(.025)\end{array}$ & $\begin{array}{c}.021 \\
(.049)\end{array}$ & $\begin{array}{c}1.00 \\
(1.02)\end{array}$ & $\begin{array}{l}-1.94 \\
(1.29)\end{array}$ & .36 & 74 \\
\hline $\begin{array}{l}\text { Revised WEO } \\
2009 \text { Growth } \\
\text { Forecast }\end{array}$ & $\begin{array}{l}-.03 \\
(.04)\end{array}$ & $\begin{array}{l}-.91^{*} \\
(.38)\end{array}$ & $\begin{array}{l}-.017 \\
(.010)\end{array}$ & $\begin{array}{c}.049 \\
(.019)\end{array}$ & $\begin{array}{l}-.00 \\
(.40)\end{array}$ & $\begin{array}{c}.05 \\
(.55)\end{array}$ & .18 & 75 \\
\hline $\begin{array}{l}\text { Output Gap } \\
2009\end{array}$ & $\begin{array}{c}.04 \\
(.08)\end{array}$ & $\begin{array}{l}-.77 \\
(.55)\end{array}$ & $\begin{array}{l}-.005 \\
(.014)\end{array}$ & $\begin{array}{l}-.021 \\
(.038)\end{array}$ & $\begin{array}{c}.59 \\
(.82)\end{array}$ & $\begin{array}{l}-1.01 \\
(2.06)\end{array}$ & .23 & 26 \\
\hline $\begin{array}{l}\text { Consumption } \\
\text { Growth } \\
2008-09\end{array}$ & $\begin{array}{c}.18 \\
(.11)\end{array}$ & $\begin{array}{c}-1.20^{*} \\
(.46)\end{array}$ & $\begin{array}{l}-.025 \\
(.015)\end{array}$ & $\begin{array}{l}-.037 \\
(.045)\end{array}$ & $\begin{array}{l}-.11 \\
(.43)\end{array}$ & $\begin{array}{l}-.44 \\
(.76)\end{array}$ & .40 & 71 \\
\hline $\begin{array}{l}\text { Extracted } \\
\text { Principal Factor }\end{array}$ & $\begin{array}{c}.01 \\
(.01)\end{array}$ & $\begin{array}{l}-.14^{*} \\
(.06)\end{array}$ & $\begin{array}{l}.006^{*} \\
(.003)\end{array}$ & $\begin{array}{c}.001 \\
(.005)\end{array}$ & $\begin{array}{l}-.07 \\
(.09)\end{array}$ & $\begin{array}{c}-.38 * * \\
(.10)\end{array}$ & .52 & 70 \\
\hline
\end{tabular}

Coefficients, with robust standard errors displayed in parentheses. Coefficients significantly different from zero at .05 (.01) significance level marked by one (two) asterisk(s). Intercept included but not recorded. Each row represents OLS estimation on the full sample. 
Table 5a: Sample Dependency

\begin{tabular}{|c|c|c|c|c|c|c|c|c|}
\hline $\begin{array}{l}\text { Sample } \\
\text { Period: }\end{array}$ & $\begin{array}{c}\text { Current } \\
\text { Account } \\
\% \text { GDP, } \\
2006\end{array}$ & $\begin{array}{c}\text { Credit Market } \\
\text { Regulation, } \\
2006\end{array}$ & $\begin{array}{l}\text { Bank } \\
\text { Credit } \\
\text { Growth } \\
\text { \%GDP, } \\
\text { 2000-06 }\end{array}$ & $\begin{array}{l}\text { US Trade } \\
\text { \%Trade, } \\
2006\end{array}$ & $\begin{array}{c}\text { Growth in } \\
\text { Market } \\
\text { Capitalization } \\
\text { 2003-06 }\end{array}$ & $\begin{array}{l}\text { Log Real } \\
\text { GDP per } \\
\text { capita, } \\
2006\end{array}$ & $\mathrm{R}^{2}$ & Obs \\
\hline All & $\begin{array}{l}.22 * * \\
(.08) \\
\end{array}$ & $\begin{array}{c}-2.01 * * \\
(.70)\end{array}$ & $\begin{array}{l}-.012 \\
(.025)\end{array}$ & $\begin{array}{l}-.002 \\
(.046)\end{array}$ & $\begin{array}{c}.85 \\
(.99) \\
\end{array}$ & $\begin{array}{c}-3.19 * * \\
(.1 .21)\end{array}$ & .41 & 75 \\
\hline $\begin{array}{l}\text { Only High } \\
\text { Income }\end{array}$ & $\begin{array}{c}.20 \\
(.11) \\
\end{array}$ & $\begin{array}{c}-.03 \\
(1.26) \\
\end{array}$ & $\begin{array}{l}-.020 \\
(.025) \\
\end{array}$ & $\begin{array}{c}.014 \\
(.061) \\
\end{array}$ & $\begin{array}{c}4.84 \\
(2.42) \\
\end{array}$ & $\begin{array}{l}-4.27 \\
(4.10) \\
\end{array}$ & .41 & 36 \\
\hline $\begin{array}{l}\text { Drop } \\
\text { Advanced } \\
\text { Economies }\end{array}$ & $\begin{array}{c}.24 \\
(.12)\end{array}$ & $\begin{array}{c}-2.44^{* *} \\
(.80)\end{array}$ & $\begin{array}{l}-.065 \\
(.068)\end{array}$ & $\begin{array}{l}-.021 \\
(.058)\end{array}$ & $\begin{array}{c}1.03 \\
(1.07)\end{array}$ & $\begin{array}{l}-3.97 \\
(2.38)\end{array}$ & .46 & 45 \\
\hline Drop Oil & $\begin{array}{l}.25^{*} \\
(.10)\end{array}$ & $\begin{array}{c}-2.13^{* *} \\
(.77)\end{array}$ & $\begin{array}{l}-.007 \\
(.026)\end{array}$ & $\begin{array}{c}.023 \\
(.053)\end{array}$ & $\begin{array}{c}.52 \\
(1.83)\end{array}$ & $\begin{array}{l}-3.36 * \\
(1.28)\end{array}$ & .44 & 68 \\
\hline $\begin{array}{l}\text { Drop } \\
\text { Financial } \\
\text { Centers }\end{array}$ & $\begin{array}{l}.22^{*} \\
(.09)\end{array}$ & $\begin{array}{c}-2.09 * * \\
(.70)\end{array}$ & $\begin{array}{l}-.031 \\
(.035)\end{array}$ & $\begin{array}{l}-.001 \\
(.051)\end{array}$ & $\begin{array}{c}.77 \\
(.99)\end{array}$ & $\begin{array}{c}-2.95^{*} \\
(1.40)\end{array}$ & .41 & 65 \\
\hline $\begin{array}{l}\text { Drop Poor, } \\
\text { Oil, and } \\
\text { Financial } \\
\text { Centers }\end{array}$ & $\begin{array}{c}.30 \\
(.15)\end{array}$ & $\begin{array}{l}-1.30 \\
(.91)\end{array}$ & $\begin{array}{l}-.039 \\
(.038)\end{array}$ & $\begin{array}{c}.020 \\
(.077)\end{array}$ & $\begin{array}{c}1.49 \\
(1.32)\end{array}$ & $\begin{array}{l}-3.41 \\
(2.42)\end{array}$ & .37 & 41 \\
\hline
\end{tabular}

Coefficients, with robust standard errors displayed in parentheses. Coefficients significantly different from zero at .05 (.01) significance level marked by one (two) asterisk(s). Intercept included but not recorded. Dependent variable: 2008-09 growth. Each row represents a separate OLS estimation.

Table 5b: Adding Extra Regressors

\begin{tabular}{|c|c|c|c|c|c|c|c|c|c|}
\hline $\begin{array}{c}\text { Current } \\
\text { Account } \\
\text { \%GDP, } \\
2006\end{array}$ & $\begin{array}{c}\text { Credit } \\
\text { Market } \\
\text { Regulation, } \\
2006\end{array}$ & $\begin{array}{c}\text { Growth } \\
\text { in Bank } \\
\text { Credit } \\
\text { \%GDP, } \\
2000-06\end{array}$ & $\begin{array}{c}\text { Trade } \\
\text { with US } \\
\text { \%Trade, } \\
2006\end{array}$ & $\begin{array}{c}\text { Growth in } \\
\text { Market } \\
\text { Capitalization } \\
2003-06\end{array}$ & $\begin{array}{c}\text { Log } \\
\text { Real } \\
\text { GDP per } \\
\text { capita, } \\
2006\end{array}$ & $\begin{array}{c}\text { ST } \\
\text { External } \\
\text { Debt } \\
\text { \%GDP, } \\
2006\end{array}$ & $\begin{array}{c}\text { Real } \\
\text { Housing } \\
\text { Price } \\
\text { Growth, } \\
2000-06\end{array}$ & $R^{2}$ & Obs \\
\hline $.22^{* *}$ & $-2.01^{* *}$ & -.012 & -.002 & .85 & $-3.19 * *$ & & & .41 & 75 \\
$(.08)$ & $(.70)$ & $(.025)$ & $(.046)$ & $(.99)$ & $(.1 .21)$ & & & & \\
\hline .12 & $-2.08^{*}$ & -.027 & -.033 & .86 & -2.47 & $-.34 *$ & & 38 \\
$(.22)$ & $(.94)$ & $(.066)$ & $(.071)$ & $(1.12)$ & $(2.94)$ & $(.14)$ & & & 38 \\
\hline .17 & -1.72 & .015 & .050 & -.50 & -4.35 & & -.042 & .43 & 43 \\
$(.13)$ & $(1.28)$ & $(.025)$ & $(1.86)$ & $(1.86)$ & $(2.51)$ & & $(.025)$ & & \\
\hline
\end{tabular}

Coefficients, with robust standard errors displayed in parentheses. Coefficients significantly different from zero at .05 (.01) significance level marked by one (two) asterisk(s). Intercept included but not recorded. Dependent variable: 2008-09 growth. Each row represents a separate OLS estimation. 
Table 6a: Narrowing the Focus Further

\begin{tabular}{|c|c|c|c|c|c|c|}
\hline Sample Period: & $\begin{array}{c}\text { Current Account } \\
\% G D P, 2006\end{array}$ & $\begin{array}{c}\text { Credit Market } \\
\text { Regulation, } 2006 \\
\end{array}$ & $\begin{array}{c}\text { Log Real GDP } \\
\text { per capita, } 2006\end{array}$ & $\begin{array}{l}\text { ST External Debt } \\
\text { \%GDP, } 2006 \\
\end{array}$ & $\mathrm{R}^{2}$ & Obs \\
\hline All & $\begin{array}{l}.21^{* *} \\
(.06)\end{array}$ & $\begin{array}{c}-2.16^{* *} \\
(.67)\end{array}$ & $\begin{array}{c}-2.98^{* *} \\
(.83)\end{array}$ & & .38 & 84 \\
\hline $\begin{array}{l}\text { All (no advanced } \\
\text { economies or FCs) }\end{array}$ & $\begin{array}{l}.05 \\
(.15) \\
\end{array}$ & $\begin{array}{c}-2.38^{*} \\
(.93) \\
\end{array}$ & $\begin{array}{l}-1.53 \\
(2.31) \\
\end{array}$ & $\begin{array}{l}-.36^{*} \\
(.13) \\
\end{array}$ & .44 & 42 \\
\hline Only High Income & $\begin{array}{l}.21^{* *} \\
(.07)\end{array}$ & $\begin{array}{c}-.51 \\
(1.30)\end{array}$ & $\begin{array}{l}-4.93 \\
(3.09)\end{array}$ & & .30 & 40 \\
\hline $\begin{array}{l}\text { Drop Advanced } \\
\text { Economies }\end{array}$ & $\begin{array}{l}.26 * * \\
(.08)\end{array}$ & $\begin{array}{c}-2.73^{* *} \\
(.79) \\
\end{array}$ & $\begin{array}{l}-3.15 \\
(1.71)\end{array}$ & & .39. & 52 \\
\hline Drop Oil & $\begin{array}{l}.22^{* *} \\
(.07)\end{array}$ & $\begin{array}{c}-2.39 * * \\
(.68)\end{array}$ & $\begin{array}{c}-2.92^{* *} \\
(.87)\end{array}$ & & .42 & 76 \\
\hline Drop Oil & $\begin{array}{l}.08 \\
(.16) \\
\end{array}$ & $\begin{array}{c}-2.59 * \\
(.97) \\
\end{array}$ & $\begin{array}{l}-1.16 \\
(2.35) \\
\end{array}$ & $\begin{array}{c}-.37 * * \\
(.14) \\
\end{array}$ & .48 & 38 \\
\hline $\begin{array}{l}\text { Drop Financial } \\
\text { Centers }\end{array}$ & $\begin{array}{l}.22^{* *} \\
(.07)\end{array}$ & $\begin{array}{c}-2.41^{* *} \\
(.69)\end{array}$ & $\begin{array}{c}-2.85^{* *} \\
(.92)\end{array}$ & & .38 & 72 \\
\hline $\begin{array}{l}\text { Drop Poor, Oil, and } \\
\text { Financial Centers }\end{array}$ & $\begin{array}{l}.27^{*} \\
(.12)\end{array}$ & $\begin{array}{l}-1.86 \\
(.95) \\
\end{array}$ & $\begin{array}{l}-3.32 \\
(1.80)\end{array}$ & & .29 & 4 \\
\hline $\begin{array}{l}\text { Drop Poor, Oil, and } \\
\text { Financial Centers }\end{array}$ & $\begin{array}{l}-.01 \\
(.21)\end{array}$ & $\begin{array}{c}-1.52 \\
(1.47)\end{array}$ & $\begin{array}{l}-1.73 \\
(10 .)\end{array}$ & $\begin{array}{l}-.43^{*} \\
(.19)\end{array}$ & .53 & 18 \\
\hline
\end{tabular}

Coefficients, with robust standard errors displayed in parentheses. Coefficients significantly different from zero at .05 (.01) significance level marked by one (two) asterisk(s). Intercept included but not recorded. Dependent variable: 2008-09 growth. Each row represents a separate OLS estimation.

Table 6b: Weighting by Population

\begin{tabular}{|c|c|c|c|c|c|}
\hline $\begin{array}{l}\text { Current Account } \\
\% \text { GDP, } 2006\end{array}$ & $\begin{array}{c}\text { Credit Market } \\
\text { Regulation, } 2006\end{array}$ & $\begin{array}{l}\text { Log Real GDP per } \\
\text { capita, } 2006\end{array}$ & $\begin{array}{l}\text { ST External Debt } \\
\text { \%GDP, } 2006\end{array}$ & $\mathrm{R}^{2}$ & Obs \\
\hline $\begin{array}{l}.22 * * \\
(.06)\end{array}$ & $\begin{array}{c}-2.11^{* *} \\
(.71)\end{array}$ & $\begin{array}{c}-3.08^{* *} \\
(.85)\end{array}$ & & .39 & 84 \\
\hline $\begin{array}{c}.09 \\
(.14)\end{array}$ & $\begin{array}{c}-2.32^{*} \\
(.96)\end{array}$ & $\begin{array}{l}-2.04 \\
(1.97)\end{array}$ & $\begin{array}{l}-.32 * \\
(.15)\end{array}$ & .43 & 42 \\
\hline
\end{tabular}

Coefficients, with standard errors displayed in parentheses. Coefficients significantly different from zero at .05 (.01) significance level marked by one (two) asterisk(s). Intercept included but not recorded. Dependent variable: 2008-09 growth. Each row represents a separate WLS estimation over all available observations, weights are log 2006 population. 
Table 7a: The 1991-92 Global Slowdown

\begin{tabular}{|c|c|c|c|c|c|}
\hline Sample Period: & $\begin{array}{c}\text { Current Account } \\
\% G D P, 1990\end{array}$ & $\begin{array}{c}\text { Credit Market } \\
\text { Regulation, } 1990\end{array}$ & $\begin{array}{c}\text { Log Real GDP per } \\
\text { capita, } 1990\end{array}$ & $\mathrm{R}^{2}$ & Obs \\
\hline All & $\begin{array}{l}.29 * * \\
(.08)\end{array}$ & $\begin{array}{l}.59^{*} \\
(.29)\end{array}$ & $\begin{array}{c}-1.15^{*} \\
(.46) \\
\end{array}$ & .20 & 103 \\
\hline Only High Income & $\begin{array}{l}.30 \\
(.16)\end{array}$ & $\begin{array}{c}.26 \\
(.58)\end{array}$ & $\begin{array}{l}-2.53 \\
(2.67)\end{array}$ & .16 & 31 \\
\hline Drop Advanced Economies & $\begin{array}{l}.24^{*} \\
(.09)\end{array}$ & $\begin{array}{l}.83^{*} \\
(.33)\end{array}$ & $\begin{array}{l}-.43 \\
(.68)\end{array}$ & .25 & 76 \\
\hline Drop Oil & $\begin{array}{l}.33^{* *} \\
(.12)\end{array}$ & $\begin{array}{c}.62 \\
(.32)\end{array}$ & $\begin{array}{c}-1.26^{*} \\
(.49)\end{array}$ & .21 & 92 \\
\hline Drop Financial Centers & $\begin{array}{l}.29 * * \\
(.09)\end{array}$ & $\begin{array}{c}.59 \\
(.30)\end{array}$ & $\begin{array}{c}-1.15^{*} \\
(.48)\end{array}$ & .20 & 95 \\
\hline $\begin{array}{l}\text { Drop Poor, Oil, and } \\
\text { Financial Centers }\end{array}$ & $\begin{array}{l}.57^{* *} \\
(.19)\end{array}$ & $\begin{array}{l}.85^{*} \\
(.32) \\
\end{array}$ & $\begin{array}{c}-3.69 * * \\
(.84) \\
\end{array}$ & .42 & 42 \\
\hline
\end{tabular}

Coefficients, with robust standard errors displayed in parentheses. Coefficients significantly different from zero at .05 (.01) significance level marked by one (two) asterisk(s). Intercept included but not recorded. Dependent variable: 1991-92 growth. Each row represents a separate OLS estimation.

Table 7b: The 2001-02 Global Slowdown

\begin{tabular}{|c|c|c|c|c|c|}
\hline Sample Period: & $\begin{array}{c}\text { Current Account } \\
\% \text { GDP, } 2000\end{array}$ & $\begin{array}{c}\text { Credit Market } \\
\text { Regulation, } 2000\end{array}$ & $\begin{array}{c}\text { Log Real GDP per } \\
\text { capita, } 2000\end{array}$ & $\mathrm{R}^{2}$ & Obs \\
\hline All & $\begin{array}{c}.03 \\
(.04) \\
\end{array}$ & $\begin{array}{l}.36 \\
(.26) \\
\end{array}$ & $\begin{array}{c}-.42 \\
(.31) \\
\end{array}$ & .09 & 112 \\
\hline Only High Income & $\begin{array}{l}.05^{*} \\
(.02)\end{array}$ & $\begin{array}{l}.55^{*} \\
(.22)\end{array}$ & $\begin{array}{c}-3.77^{* *} \\
(.82)\end{array}$ & .44 & 39 \\
\hline Drop Advanced Economies & $\begin{array}{l}-.05 \\
(.06)\end{array}$ & $\begin{array}{l}-.49 \\
(.33)\end{array}$ & $\begin{array}{l}-.33 \\
(.57)\end{array}$ & .07 & 80 \\
\hline Drop Oil & $\begin{array}{l}-.06 \\
(.07) \\
\end{array}$ & $\begin{array}{l}-.35 \\
(.29) \\
\end{array}$ & $\begin{aligned}-. .43 \\
(.32) \\
\end{aligned}$ & .10 & 101 \\
\hline Drop Financial Centers & $\begin{array}{l}.05 \\
(.05)\end{array}$ & $\begin{array}{l}-.41 \\
(.28)\end{array}$ & $\begin{array}{l}-.45 \\
(.33)\end{array}$ & .10 & 102 \\
\hline $\begin{array}{l}\text { Drop Poor, Oil, and } \\
\text { Financial Centers }\end{array}$ & $\begin{array}{l}.06 \\
(.05) \\
\end{array}$ & $\begin{array}{l}.71^{*} \\
(.34) \\
\end{array}$ & $\begin{array}{l}-.90^{*} \\
(.36) \\
\end{array}$ & .10 & 49 \\
\hline
\end{tabular}

Coefficients, with robust standard errors displayed in parentheses. Coefficients significantly different from zero at .05 (.01) significance level marked by one (two) asterisk(s). Intercept included but not recorded. Dependent variable: 2001-02 growth. Each row represents a separate OLS estimation. 
Appendix Table A1: List of Included Countries/Territories

\begin{tabular}{|c|c|c|}
\hline Albania & Algeria $^{c}$ & Antigua \& Barbuda ${ }^{a}$ \\
\hline Argentina & Armenia & Australia $^{a, b}$ \\
\hline Austria ${ }^{a, b}$ & Bahamas $^{a, d}$ & Bahrain $^{a, c, d}$ \\
\hline Barbados $^{\text {a,d }}$ & Belarus & Belgium $^{a, b, d}$ \\
\hline Bermuda $^{a, d}$ & Botswana & Brazil \\
\hline Brunei Darussalam ${ }^{a, c}$ & Bulgaria & Canada $^{a, b}$ \\
\hline Chile & China & Colombia \\
\hline Costa Rica & Croatia & Cuba \\
\hline Cyprus $^{a, b}$ & Czech Rep ${ }^{a, b}$ & Denmark $^{a, b}$ \\
\hline Dominican Rep & Ecuador $^{c}$ & Egypt \\
\hline El Salvador & Eq. Guinea ${ }^{a, c}$ & Estonia $^{a}$ \\
\hline Finland $^{\mathrm{a}, \mathrm{b}}$ & France $^{\mathrm{a}, \mathrm{b}}$ & Gabon $^{\mathrm{c}}$ \\
\hline Georgia & Germany ${ }^{a, b}$ & Greece $^{a, b}$ \\
\hline Guyana & Haiti & Hong Kong ${ }^{a, b, d}$ \\
\hline Hungary $^{a}$ & Iceland ${ }^{a, b, d}$ & Indonesia \\
\hline $\operatorname{Iran}^{c}$ & Ireland $^{a, b, d}$ & Israel ${ }^{\mathrm{a}, \mathrm{b}}$ \\
\hline Italy $a, b$ & Jamaica & Japan $^{\text {a, b }}$ \\
\hline Kazakhstan $^{\mathrm{c}}$ & Korea $^{a, b, d}$ & Kuwait $^{\text {a, c }}$ \\
\hline Kyrgyz Republic & Latvia & Lebanon \\
\hline Libya $^{c}$ & Lithuania & Luxembourg $^{a, b, d}$ \\
\hline Macau $^{a, d}$ & Macedonia & Malaysia \\
\hline Malta ${ }^{a, b, d}$ & Mauritius & Mexico \\
\hline Morocco & Namibia & Netherlands ${ }^{a, b}$ \\
\hline Netherlands Antilles ${ }^{\text {a, d }}$ & New Zealand ${ }^{\mathrm{a}, \mathrm{b}}$ & Norway ${ }^{a, b}$ \\
\hline $\operatorname{Oman}^{\mathrm{a}, \mathrm{c}}$ & Panama & Papua New Guinea \\
\hline Paraguay & Peru & Poland \\
\hline Portugal ${ }^{a, b}$ & Puerto Rico $^{\text {a }}$ & Qatar $^{\mathrm{a}, \mathrm{c}}$ \\
\hline Romania & Russia $^{c}$ & Saudi Arabia ${ }^{a, c}$ \\
\hline Seychelles & Singapore ${ }^{a, b, d}$ & Slovakia $^{\mathrm{a}, \mathrm{b}}$ \\
\hline Slovenia $^{\mathrm{a}, \mathrm{b}}$ & South Africa & Spain $^{\mathrm{a}, \mathrm{b}}$ \\
\hline Sri Lanka & St. Kitts \& Nevis & Swaziland \\
\hline Sweden ${ }^{a, b}$ & Switzerland ${ }^{a, b, d}$ & Taiwan $^{a, b, d}$ \\
\hline Thailand & Trinidad \& Tobago ${ }^{a, c}$ & Tunisia \\
\hline Turkey & Turkmenistan $^{\mathrm{c}}$ & $\mathrm{UK}^{\mathrm{a}, \mathrm{b}}$ \\
\hline Ukraine & United Arab Emirates ${ }^{\text {a, } c}$ & United States $^{\mathrm{a}, \mathrm{b}}$ \\
\hline Uruguay & Venezuela $^{c}$ & \\
\hline
\end{tabular}

Notes: a denotes World Bank high income country; b denotes IMF advanced economy; c denotes oil economy; $d$ denotes small financial center. 
Appendix Table A2a: The 1991-92 Global Slowdown: Sensitivity Analysis

\begin{tabular}{|c|c|c|c|c|c|c|c|}
\hline $\begin{array}{c}\text { Current } \\
\text { Account } \\
\% G D P, \\
1990\end{array}$ & $\begin{array}{c}\text { Credit Market } \\
\text { Regulation, } \\
1990\end{array}$ & $\begin{array}{l}\text { Log Real } \\
\text { GDP per } \\
\text { capita, } \\
1990\end{array}$ & $\begin{array}{c}\text { Bank } \\
\text { Credit } \\
\text { Growth, } \\
1985-90\end{array}$ & $\begin{array}{l}\text { Private } \\
\text { Sector } \\
\text { Growth, } \\
1985-90\end{array}$ & $\begin{array}{c}\text { ST } \\
\text { External } \\
\text { Debt } \\
\text { \%GDP, } \\
1990\end{array}$ & $\mathrm{R}^{2}$ & Obs \\
\hline $\begin{array}{l}.29 * * \\
(.08) \\
\end{array}$ & $\begin{array}{l}.59 * \\
(.29)\end{array}$ & $\begin{array}{c}-1.15^{*} \\
(.46)\end{array}$ & & & & .20 & 103 \\
\hline $\begin{array}{l}.25^{* *} \\
(.09)\end{array}$ & $\begin{array}{c}.37 \\
(.27)\end{array}$ & $\begin{array}{l}-.77 \\
(.47)\end{array}$ & $\begin{array}{l}-.01 \\
(.02)\end{array}$ & & & .16 & 96 \\
\hline $\begin{array}{l}.24^{* *} \\
(.08)\end{array}$ & $\begin{array}{c}.17 \\
(.25)\end{array}$ & $\begin{array}{l}-.55 \\
(.46)\end{array}$ & & $\begin{array}{l}-.01 \\
(.03)\end{array}$ & & .12 & 96 \\
\hline $\begin{array}{l}.28^{* *} \\
(.10)\end{array}$ & $\begin{array}{l}.79 * \\
(.30)\end{array}$ & $\begin{array}{c}.03 \\
(.68)\end{array}$ & & & $\begin{array}{l}.03^{*} \\
(.01)\end{array}$ & .28 & 68 \\
\hline
\end{tabular}

Dependent Variable: Change in Growth Rate, from 1985-90 to 1991-92.

\begin{tabular}{|c|c|c|c|c|c|c|c|}
\hline $.22^{*}$ & .13 & -.66 & & & & .08 & 101 \\
$(.10)$ & $(.30)$ & $(.47)$ & & & & & \\
\hline
\end{tabular}

Coefficients, with robust standard errors displayed in parentheses. Coefficients significantly different from zero at .05 (.01) significance level marked by one (two) asterisk(s). Intercept included but not recorded. Dependent variable: 1991-92 growth unless indicated. All available countries included. Each row represents a separate OLS estimation.

Appendix Table A2b: The 2001-02 Global Slowdown: Sensitivity Analysis

\begin{tabular}{|c|c|c|c|c|c|c|c|}
\hline $\begin{array}{c}\text { Current } \\
\text { Account } \\
\% G D P \text {, } \\
2000\end{array}$ & $\begin{array}{c}\text { Credit Market } \\
\text { Regulation, } \\
2000\end{array}$ & $\begin{array}{l}\text { Log Real } \\
\text { GDP per } \\
\text { capita, } \\
2000\end{array}$ & $\begin{array}{c}\text { Bank } \\
\text { Credit } \\
\text { Growth, } \\
1995- \\
2000\end{array}$ & $\begin{array}{c}\text { Private } \\
\text { Sector } \\
\text { Growth, } \\
1995- \\
2000\end{array}$ & $\begin{array}{c}\text { ST } \\
\text { External } \\
\text { Debt } \\
\text { \%GDP, } \\
2000\end{array}$ & $\mathrm{R}^{2}$ & Obs \\
\hline $\begin{array}{l}-.03 \\
(.04)\end{array}$ & $\begin{array}{l}-.36 \\
(.26)\end{array}$ & $\begin{array}{c}-.42 \\
(.31)\end{array}$ & & & & .09 & 112 \\
\hline $\begin{array}{l}-.03 \\
(.05)\end{array}$ & $\begin{array}{l}-.36 \\
(.26)\end{array}$ & $\begin{array}{l}-.43 \\
(.31)\end{array}$ & $\begin{array}{c}.00 \\
(.01)\end{array}$ & & & .09 & 112 \\
\hline $\begin{array}{l}-.03 \\
(.05)\end{array}$ & $\begin{array}{l}-.35 \\
(.26)\end{array}$ & $\begin{array}{l}-.45 \\
(.31)\end{array}$ & & $\begin{array}{c}.00 \\
(.01) \\
\end{array}$ & & .09 & 111 \\
\hline $\begin{array}{l}-.09 \\
(.08)\end{array}$ & $\begin{array}{l}-.85 \\
(.44)\end{array}$ & $\begin{array}{l}-.59 \\
(.60)\end{array}$ & & & $\begin{array}{c}-.01 \\
(.07)\end{array}$ & .15 & 71 \\
\hline
\end{tabular}

Dependent Variable: Change in Growth Rate, from 1995-2000 to 20001-02.

\begin{tabular}{|c|c|c|c|c|c|c|c|}
\hline .00 & $-.69 *$ & -.41 & & & & .11 & 112 \\
$(.06)$ & $(.30)$ & $(.32)$ & & & & & \\
\hline
\end{tabular}

Coefficients, with robust standard errors displayed in parentheses. Coefficients significantly different from zero at .05 (.01) significance level marked by one (two) asterisk(s). Intercept included but not recorded. Dependent variable: 2001-02 growth unless indicated. All available countries included. Each row represents a separate OLS estimation. 


\section{Endnotes}

${ }^{1}$ We note in passing that the number of observations we have is small. This is not because we are taking a small sample from a large population, but because the population itself is small.

2 Institutional Investor states that their ratings "... are based on information provided by senior economists and sovereign-risk analysts at leading global banks and money management and securities firm"; further details are available at: http://www.iimagazinerankings.com/rankingsRankCCMaGlobal09/methodology.asp.

3 "To obtain the overall country risk score, Euromoney assigns a weighting to seven categories. These are political risk (30\% weighting), economic performance (30\%), debt indicators (7.5\%), debt in default or rescheduled $(5 \%)$, credit ratings (7.5\%), access to bank finance/capital markets (10\%), discount on forfaiting (10\%)." Further details are available at http://www.euromoney.com/Print.aspx?ArticlelD=2404432. Switching from Institutional Investor to Euromoney is done strictly for convenience; the correlation coefficient between the two sets of ratings is above .95 in previous samples; we chose Institutional Investor only for RS only because it offers a slightly large sample, and we showed in RS that our results were insensitive to the choice of Euromoney instead of Institutional Investor.

${ }^{4}$ Our normalization implies that the latent variable estimate should be interpreted as decreasing in crisis severity.

${ }^{5}$ One could imagine transforming any or all of our continuous variables intro discrete binary variables, as is traditional for the banking and currency crisis literatures.

${ }^{6}$ Only the first of the four (unrotated) principal factors has an eigenvalue greater than one; the other three factors are negative. The scoring weights and factor loadings are all intuitively signed, being positive on the changes in growth, the stock market and country risk, and negative for the increase in the price of the SDR.

7 These measures are also correlated with the crisis measure we used in RS, but not perfectly. For instance, we found that the country with the most intense 2008 crisis was Iceland, but its $5.6 \%$ decline in real GDP over 2008-09 made it only the fourteenth-worst hit country using that metric (the Baltics shrank much more). Similarly, Argentina was ranked by RS to be one of the top five crisis countries in 2008 primarily on financial criteria, but over 2008-09 Argentina beat most other countries if one considers only growth.

8 The World Bank defines high-income countries as those with $2008 \mathrm{GNI}$ per capita of at least $\$ 11,906$, while upper-middle income countries are those income of at least $\$ 3,856$; http://data.worldbank.org/about/countryclassifications. The IMF's groups are at http://www.imf.org/external/pubs/ft/weo/2010/01/weodata/groups.htm. We follow Lane and Milesi-Ferretti (2010) in defining oil exporters as the OPEC members in the sample along with Bahrain, Brunei, Equatorial Guinea, Gabon, Kazakhstan, Oman, Russia, Trinidad \& Tobago, and Turkmenistan. We also follow Lane and Milesi-Ferretti (2010) in their definition of small financial centers, but also add four countries that are not in their sample (Bahamas, Barbados, Bermuda, and Netherlands Antilles).

${ }^{9}$ We have done considerable sensitivity analysis (available online) to ensure that our results are robust with respect to slightly different measures of the regressor.

10 We have also investigated four other ratios of reserves, comparing them to external debt, short-term debt, imports, and $\mathrm{M} 2$; we never find strong results.

${ }^{11}$ We have also examined the index of labor market regulation from the Economic Freedom of the World database without success; it is rarely correlated with our measures of crisis incidence.

12 It should be noted that the results of Table 3 contain considerable pre-test bias, since we only pursued potential crisis causes that had worked successfully for other scholars. 
${ }^{13}$ After the first draft of this paper was written, Frankel and Saravelos (2010) found that various measures of reserves seem to work in helping predict the cross-country incidence of the 2008-09 crisis using a variety of manifestations of crisis severity. We have examined a number of different measures of reserves using our techniques without much success.

${ }^{14}$ Sensitivity analysis available online presents comparable (often weaker) OLS results for the other crisis measures. The four columns at the right of Table 1 record estimates when these regressors are added to the MIMIC model.

${ }^{15}$ We use a bandwidth of .5, though changing this has little effect on our results. Also, we use the full sample of observations and do not control for the short-term external debt/GDP ratio in each of the graphs, except for the lower-right one (where we examine short-term external debt itself). 